\title{
Cheese whey permeate valorization using sequential fermentations: case study performed in the Western Region of Paraná
}

\author{
Valorização do permeado de soro de queijo aplicando fermentações sequenciais: estudo de caso \\ realizado na Região Oeste do Paraná \\ Valorización de permeado de suero de queso aplicando fermentaciones secuenciales: estudio de \\ caso realizado en la Región Occidental de Paraná
}

Received: 09/26/2021 | Reviewed: 10/04/2021 | Accept: 10/08/2021| Published: 10/10/2021

\author{
Keiti Lopes Maestre \\ ORCID: https://orcid.org/0000-0002-5759-4597 \\ West Paraná State University, Brazil \\ E-mail: keiti_maestre@hotmail.com \\ Fernanda Rengel dos Passos \\ ORCID: https://orcid.org/0000-0003-4955-2933 \\ West Paraná State University, Brazil \\ E-mail: frengel.passos@gmail.com \\ Carina Contini Triques \\ ORCID: https://orcid.org/0000-0002-0397-958X \\ West Paraná State University, Brazil \\ E-mail: carinatriques@ hotmail.com \\ Leila Denise Fiorentin-Ferrari \\ ORCID: https://orcid.org/0000-0001-6666-2160 \\ West Paraná State University, Brazil \\ E-mail: leiladeniseff@gmail.com \\ Veronice Slusarski-Santana \\ ORCID: https://orcid.org/0000-0001-6246-0174 \\ West Paraná State University, Brazil \\ E-mail: veronice.santana@unioeste.br \\ Helio Alves Garcia \\ ORCID: https://orcid.org/0000-0003-0872-3791 \\ Sooro Renner Nutrição S.A., Brazil \\ E-mail: h.garcia@sooro.com.br \\ Edson Antônio da Silva \\ ORCID: https://orcid.org/0000-0003-3978-5346 \\ West Paraná State University, Brazil \\ E-mail: edsondeq@hotmail.com \\ Mônica Lady Fiorese \\ ORCID: https://orcid.org/0000-0001-5250-7178 \\ West Paraná State University, Brazil \\ E-mail: mlfiorese@gmail.com
}

\begin{abstract}
Sooro Renner Nutrição S.A. company is found in the Western Region of Paraná/Brazil, which is highlighted nationally and in Latin America concerning the production of whey protein concentrate (WPC). During the production of WPC, performed in ultrafiltration membranes, the subproduct cheese whey permeate (CWP) is generated, which is rich in nutrients, such as lactose, minerals, and vitamins. This subproduct is reported as a potential culture medium to grow microorganisms. Thus, this research, performed in partnership with the Sooro company, aimed to develop biotechnological products employing sequential fermentations to fully use this subproduct bioconverting the ethanol obtained from CWP into vinegar employing the acetic bacterium Acetobacter aceti and different methods - Orleans, aerated, and stirred. The biotransformation into ethanol was performed by Kluyveromyces marxianus (alcoholic fermentation step) using a $2^{3}$ factorial experimental design to investigate the influence of lactose concentration, temperature, and $\mathrm{pH}$. The maximum ethanol production was $47.18 \pm 0.05 \mathrm{~g} \mathrm{~L}^{-1}$, employing the conditions $88 \mathrm{~g} \mathrm{~L}^{-1}$ of lactose, $29^{\circ} \mathrm{C}$, and pH 4.5 in $45 \mathrm{~h}$. Besides ethanol, probiotic cellular biomass, prebiotic galacto-oligosaccharides, and organic acids were also produced. In the oxidation stage, the Orleans method presented the best production: $42.30 \pm 0.08$ $\mathrm{g} \mathrm{L}^{-1}$ of acetic acid in 21 days. After this production, reductions of chemical oxygen demand and biochemical oxygen demand of the CWP were 60 and $65 \%$, respectively. The results showed the great potential of CWP as a fermentation medium to obtain biotechnological products as a rentable and viable alternative to fully use CWP.
\end{abstract}

Keywords: Cheese whey; Cheese whey permeate; Acetic acid; Ethanol; Acetate overoxidation; Orleans. 


\begin{abstract}
Resumo
Na região Oeste do Paraná encontra-se a empresa Sooro Renner Nutrição S.A., a qual é destaque nacional e na America Latina quanto a produção de concentrado proteico de soro de leite (CPS). Durante sua produção, realizada em membranas de ultrafiltração, ocorre a geração do subproduto permeado de soro de leite (PSL), o qual é rico em nutrientes, como lactose, minerais e vitaminas. O PSL é relatado como um meio de cultura potencial para o crescimento microbiano. Assim, esta pesquisa, realizada em parceria com a empresa Sooro, objetivou desenvolver produtos empregando fermentações sequenciais para aproveitamento integral deste subproduto bioconvertendo o etanol obtido do PSL em vinagre pela bactéria acética Acetobacter aceti e diferentes métodos-Orleans, aerado e agitado. A biotransformação em etanol foi realizada por Kluyveromyces marxianus (fermentação alcoólica) utilizando um planejamento experimental fatorial $2^{3}$ investigando a influência da concentração de lactose, temperatura e pH. A produção máxima de etanol foi de $47,18 \pm 0,05 \mathrm{~g} \mathrm{~L}^{-1}$, nas condições de $88 \mathrm{~g} \mathrm{~L}^{-1}$ de lactose, $2{ }^{\circ} \mathrm{C}$ e pH $4,5 \mathrm{em} 45 \mathrm{~h}$. Além do etanol, biomassa celular probiótica, galacto-oligossacarídeos prebióticos e ácidos orgânicos também foram

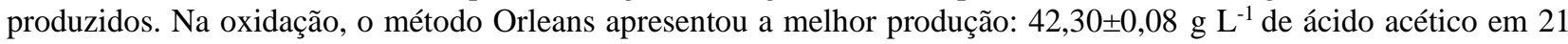
dias. Após essa produção, as reduções das demandas química e bioquímica de oxigênio do PSL foram de 60 e $65 \%$, respectivamente. Os resultados mostraram o potencial do PSL como meio de fermentação para a obtenção de produtos biotecnológicos como alternativa rentável e viável para o uso pleno do PSL.
\end{abstract}

Palavras-chave: Soro de queijo; Permeado de soro de queijo; Ácido acético; Etanol; Superoxidação de acetato; Orleans.

\title{
Resumen
}

La empresa Sooro Renner Nutrição S.A. se encuentra en la Región Oeste de Parana/Brasil, se destaca nacionalmente y en América Latina por la producción de concentrado de proteína de suero (CPS). Durante la producción, realizada en membranas de ultrafiltración, se genera el subproducto permeado de suero de queso (PSQ), el cual es rico en nutrientes, como lactosa, minerales y vitaminas. Este subproducto se informa como un medio de cultivo potencial para microorganismos. Así, esta investigación, realizada en sociedad con la empresa Sooro, tuvo como objetivo desarrollar productos empleando fermentaciones secuenciales para aprovechar plenamente este subproducto bioconvertir el etanol obtenido de PSQ en vinagre empleando la bacteria acética Acetobacter aceti y diferentes métodos-Orleans, aireado y revuelto. La biotransformación en etanol fue realizada por Kluyveromyces marxianus (fermentación alcohólica) utilizando un diseño experimental factorial $2^{3}$ para investigar la influencia de la concentración de lactosa, temperatura y $\mathrm{pH}$. La producción máxima de etanol fue $47,18 \pm 0,05 \mathrm{~g} \mathrm{~L}^{-1}$, empleando las condiciones $88 \mathrm{~g} \mathrm{~L}^{-1}$ de lactosa, $29^{\circ} \mathrm{C} \mathrm{y} \mathrm{pH}$ 4,5 en $45 \mathrm{~h}$. Además de etanol, también se produjeron biomasa celular probiótica, galactooligosacáridos prebióticos y ácidos orgánicos. En fermentaión acética, el método Orleans presentó la mejor producción: $42,30 \pm 0,08 \mathrm{~g} \mathrm{~L}^{-1}$ de ácido acético en 21 días. Después de esta producción, las reducciones de la demanda química y bioquímica de oxígeno del PSQ fueron del 60 y 65\%, respectivamente. Los resultados mostraron potencial de PSQ como medio de fermentación para obtener productos biotecnológicos como una alternativa rentable y viable para utilizar plenamente PSQ.

Palabras clave: Suero de queso; Permeado de suero de queso; Ácido acético; Etanol; Sobreoxidación de acetato; Orleans.

\section{Introduction}

$\approx 32 \%$ of the total volume of milk produced is employed in cheese production in Brazil (USDA, 2017). According to statistical data, in 2019, the cheese production in Brazil was 770 hundred tons (Key et al., 2021).

Considering that each kilo of cheese produced generates around 9 liters of cheese whey, 10.3 million liters of cheese whey are estimated to have been produced globally in 2017, with a growth rate estimated at 1 to $2 \%$ every year (ABIQ, 2018). From this total, only 145 million tons, equivalent to an average of 50-60\%, are industrially used, while the remaining is destined for animal feed, and a small portion, used as fertilized or even discarded as waste (Ganju \& Gogate, 2017).

The main use of cheese whey in a rentable way is to produce protein. Around 1.5 million tons of protein constituents with high biological value are produced from cheese whey, which drives a growing market for the production of protein concentrates, known commercially as whey protein concentrate (WPC) protein isolates, protein hydrolysates, among other products (Khezri S., M.M., I., M., \& P., 2016). This exploration concerning cheese whey protein is due to advanced technologies of ultrafiltration, nanofiltration, and reverse osmosis (Carvalho, Prazeres, \& Rivas, 2013; M. Marx \& Kulozik, 2018).

In the cheese whey protein concentration process, it passes through a membrane filtration system, achieving a retentate product at the end, composed of proteins, fats, colloidal minerals, and a liquid that permeates (passes) through the membrane, originating the cheese whey permeate (CWP) (Andrade \& Martins, 2002; Lagrange \& Dallas, 1997; Zacarchenco et al., 2012). 
According to data provided by the Sooro Renner Nutrição S.A. company (2020), the cheese whey quantity used to obtain the protein concentrates ranges according to the protein quantity required in the final product. For example, to produce WPC containing $35 \%$ of protein, $26 \mathrm{~kg}$ of cheese whey or milk is necessary, resulting in $1 \mathrm{~kg}$ of WPC $35 \%$ and $2.3 \mathrm{~kg}$ of CWP, while the production of $1 \mathrm{~kg}$ of WPC $80 \%$ of protein, generates around $8 \mathrm{~kg}$ of CWP.

CWP contains around $5 \%$ and $6 \%$ of solids. Its composition on a dry basis is of approximately $85 \%$ lactose, $10 \%$ ashes, and $>3 \%$ protein (Illanes, 2016). Due to this composition, it is a favorable growth medium for biotechnological processes applications (Diniz, Silveira, Fietto, \& Passos, 2012; Passos et al., 2021). Because the permeate can be fully used as a culture medium, the necessity to remediate and the costs involved with its treatment are eliminated (Murari, Silva, Schuina, Mosinhahti, \& Bianchi, 2018; Trigueros et al., 2016), representing an interesting opportunity to obtain value-added products, economically and sustainably.

Vinegar is an aqueous solution of acetic acid (AA) and other constituents, obtained through a biotechnological process of double fermentation: alcoholic and acetic, in which the substrate (carbohydrate source) is fermented by yeasts to produce ethanol, and this product is then converted to AA by acetic bacteria (Gomes, Borges, Rosa, Castro-Gómez, \& Spinosa, 2018; Pazuch et al., 2020). In addition to being traditionally used as a food preservative, AA is also a solvent or an intermediary input to several commercial chemical products (Pal \& Nayak, 2017) and medical applications (Dong et al., 2020; Ho, Lazim, Fazry, Zaki, \& Lim, 2017).

Vinegar consumption is associated with several benefits to health, such as potential antimicrobial and antioxidant agents, aids in the modulation of blood glucose control, possesses positive effects for the cardiovascular system, such as regulation of lipid metabolism, and anti-hypertensive action. Also, its action is reported as effective in weight loss, reduction of fatigue, and anti-cancer activity (Budak, Aykin, Seydim, Greene, \& Guzel-Seydim, 2014; Chen, Chen, Giudici, \& Chen, 2016; Lynch, Zannini, Wilkinson, Daenen, \& Arendt, 2019).

The most common technological processes used in the mentioned acetic fermentation stage are the Orleans process, the Generator process, and The Submerged process (Guizani \& Mothershaw, 2006) and the main raw materials used to produce vinegar are wine, cider, beer, and other liqueurs derived from the alcoholic fermentation of cereals, fruits, and starchy materials, or sugar solutions, such as molasses and honey, and also pure ethanol diluted with nutrients addition (Raspor \& Goranovič, 2008). The use of dairy sources has also been reported (Lustrato et al., 2013; Parrondo, Herrero, García, Díaz, \& Brew, 2003).

Another issue to be considered in a biotechnological process is the microorganism choice. Most of the studies that produce alcohol use the yeast Saccharomyces cerevisiae, and posteriorly, the acetic fermented is obtained using acetic bacteria from the genus Acetobacter and Gluconobacter (Pazuch et al., 2020; Samuel, Lina, \& Ifeanyi, 2016).

However, the yeast Kluyveromyces marxianus has demonstrated the potential to be applied in the alcoholic fermentation and has aroused the interest of the biotechnology area compared with other yeast species, due to its metabolic diversity and its capacity to assimilate several sugars, besides presenting a more elevated growth rate and a broad spectrum of thermotolerance (Lane \& Morrissey, 2010; Yadav et al., 2015). Strains of this yeast grow well in a culture medium containing lactose and galactose (Christensen, Kádár, Oleskowicz-Popiel, \& Thomsen, 2011), proven by several studies that produced ethanol from lactose (Murari, Machado, Schuina, \& Bianchi, 2019).

Besides, it grows at a wide range of temperature $\left(30\right.$ to $52^{\circ} \mathrm{C}$ ) (Lane \& Morrissey, 2010), and pH (4.5 to 6.5) (Yadav et al., 2015). Because it is a yeast classified as Crabtree-negative, it can perform, simultaneously, fermentation and respiration processes, thus favoring cellular biomass production as well. The cells of this yeast are an alternative protein source for food supplements for humans and animals (Haddish, 2015). Recently, many researchers have introduced this yeast as a potential probiotic microorganism, due to the capacity of modifications in the cell immunity, adhesion, and human gut microbiota (Karim, Gerliani, \& Aïder, 2020). Several authors still report that the hydrolyzed from K. marxianus cells possesses antioxidant, 
antihypertensive (Mirzaei, Mirdamadi, Ehsani, \& Aminlari, 2018), anti-inflammatory (Cho et al., 2018) and hypocholesterolemic (Xie et al., 2015) bioactive properties.

The acetic bacteria Acetobacter aceti is an important microorganism in the production of fermented foods and beverages (including vinegar, kombucha, lambic beers, kefir and others) (Lynch et al., 2019). It is used in the acetic stage to produce vinegar, has a high capacity to oxidize ethanol into AA and high resistance to the AA released in the fermentation medium (Nakano \& Fukaya, 2008). This species grows considerably well in temperatures between 25 and $30^{\circ} \mathrm{C}$ (Samuel et al., 2016), and between pH 4.0 and 6.0 (Sievers \& Swings, 2015). Many factors can influence the A. aceti growth, among them: temperature, pH, oxygen, ethanol, and AA concentration (Guillamón \& Mas, 2011).

Sooro Renner Nutrição S.A. company, with plants located in the Western Region of Paraná and northwest region of Rio Grande do Sul daily processes 3.4 million liters of cheese whey/cheese. It operates in the sports nutrition, ingredients, and animal nutrition segments. Currently, it stands out on the national scene as one of the largest producers of CWP and cheese whey pow der. It is the biggest producer of whey protein $(80 \%, 60 \%$, and $34 \%$ ) in Latin America and the only industry to produce whey protein isolated 90\% in Brazil and Latin America (Garcia, 2021). It has an installed capacity for the production of powdered CWP (with $15 \%$ solids) of about 3000 tons/month totaling approximately 240,000 tons/year of this product (data provided by the company). Because Sooro is an innovative company in the dairy segment in Brazil, it is always searching to support and motivate the development of technological research to add value to the dairy production chain.

Thus, this study aimed, in partnership with Sooro Renner Nutrição S.A. company, to develop biotechnological products employing sequential fermentations to fully use the subproduct CWP. So, fermentations in different conditions with CWP and the yeast Kluyveromyces marxianus CCT 4086 were performed to find the most favorable condition to produce ethanol. Then, ethanol was oxidized into AA by different acetic methods: Orleans, Aerated, and Stirred methods with the bacterium Acetobacter aceti CCT 2565. In each step of the fermentative processes, the biotechnological products generated were quantified, and, through measurements of chemical oxygen demand (COD) and biochemical oxygen demand (BOD), the organic load reduction was determined.

\section{Material and Methods}

\subsection{Feedstock}

The feedstock used as substrate was CWP from the protein concentrate process and ceded by the industry Sooro Renner Nutrição S.A. located in the west region of Paraná state, Brazil. Its composition was lactose ( $88 \%$ w/w), protein $(3.23 \%$ w/w), potassium $(0.06 \% \mathrm{w} / \mathrm{w})$, magnesium $(0.05 \% \mathrm{w} / \mathrm{w})$, sodium $(0.60 \% \mathrm{w} / \mathrm{w})$, and calcium $(0.25 \% \mathrm{w} / \mathrm{w})$.

\subsection{Microorganisms}

The lyophilized Kluyveromyces marxianus CCT 4086 (reference ATCC 46537) and Acetobacter aceti CCT 2565 (reference ATCC 15973) were provided by the Tropical Culture Collection of André Tosello Foundation (Campinas, Brazil).

\subsection{Alcoholic fermentation}

The Kluyveromyces marxianus cells were activated in $250 \mathrm{~mL}$ adapted YMA (yeast malt extract agar), composed of yeast extract $\left(3 \mathrm{~g} \mathrm{~L}^{-1}\right)$, peptone $\left(5 \mathrm{~g} \mathrm{~L}^{-1}\right)$, and dextrose $\left(10 \mathrm{~g} \mathrm{~L}^{-1}\right)$. The medium culture was sterilized at $121{ }^{\circ} \mathrm{C}$ for $15 \mathrm{~min}$ in an autoclave. The flasks were incubated in an orbital shaker at $30^{\circ} \mathrm{C}$ and $100 \mathrm{rpm}$ for $24 \mathrm{~h}$. The yeast was kept in YMA medium with agar-agar $\left(20 \mathrm{~g} \mathrm{~L}^{-1}\right)$ in tubes for $48 \mathrm{~h}$ at $30^{\circ} \mathrm{C}$ in a microbiological growth oven. After that, the tubes were stored in a refrigerator at $4{ }^{\circ} \mathrm{C}$. 
The cultivation inoculum was activated in $270 \mathrm{~mL}$ of a medium consisting of lactose $\left(88 \mathrm{~g} \mathrm{~L}^{-1}\right)$, urea $\left(6 \mathrm{~g} \mathrm{~L}^{-1}\right)$, magnesium sulfate $\left(1.5 \mathrm{~g} \mathrm{~L}^{-1}\right)$, monobasic potassium phosphate $\left(1.5 \mathrm{~g} \mathrm{~L}^{-1}\right)$, and yeast extract $\left(6 \mathrm{~g} \mathrm{~L}^{-1}\right)$ autoclaved for $15 \mathrm{~min}$ at $121^{\circ} \mathrm{C}$. Then, $10 \%$ of the YMA medium (pre-inoculum) was transferred to the cultivation medium (inoculum). Lactose medium was pasteurized at $65^{\circ} \mathrm{C}$ for $30 \mathrm{~min}$ in a drying and sterilization oven (Parrondo et al., 2003), pH 5.5, and was incubated in an orbital shaker at $100 \mathrm{rpm}$ and $37^{\circ} \mathrm{C}$ for $24 \mathrm{~h}$.

Cultures were started with $1800 \mathrm{~mL}$ of fermentation medium to a final volume of $2 \mathrm{~L}$, thus, the quantity of inoculum corresponded to $10 \%(\mathrm{v} / \mathrm{v})$, which were transferred to the cultivations, consisting of the same concentrations of urea, magnesium sulfate, monobasic potassium phosphate, and yeast extract, and lactose concentrations defined according to the levels of the experimental design. The fermentations were conducted for $45 \mathrm{~h}$ and incubated in an orbital shaker at $100 \mathrm{rpm}$.

The kinetics of all cultivations were accompanied by measurements of ethanol, probiotic cellular biomass, lactose concentration, $\mathrm{pH}$, organics acids, and galacto-oligosaccharides (GOS). Absorbance and $\mathrm{pH}$ were read as soons as the samples were taken. $11 \mathrm{~mL}$ was centrifuged at $14000 \mathrm{rpm}$ for $5 \mathrm{~min}$. The supernatant and the precipitated were separated and stored in a freezer at $-10^{\circ} \mathrm{C}$ for further analysis of sugar (substrate concentration), and ethanol.

\subsection{Alcoholic fermentations experimental design and statistical analyses}

A $2^{3}$ factorial design with triplicate at the center point was used. Temperature $\left(\mathrm{X}_{1}\right), \mathrm{pH}\left(\mathrm{X}_{2}\right)$, and lactose concentration of CWP $\left(\mathrm{X}_{3}\right)$ were the independent variables evaluated at three levels $(-1,0,+1)$. The response variable is ethanol concentration $\left(\mathrm{g} \mathrm{L}^{-1}, \mathrm{v} / \mathrm{v}\right)(\mathrm{Y})$, which, after statistical analysis, could be represented by the polynomial model equation (Eq. 1), where $\mathrm{b}$ values are the intercepts. The levels were selected based on results from preliminary experiments, not shown in this article.

$$
Y=b_{0}+b_{1} X_{1}+b_{2} X_{2}+b_{3} X_{3}+b_{4} X_{1}: X_{2}+b_{5} X_{1}: X_{3}+b_{6} X_{2}: X_{3}
$$

The yeast cultivation performance was evaluated at the end of $45 \mathrm{~h}$. The experimental design was analyzed by the Statistica ${ }^{\mathrm{TM}}$ software, version 8.0 (StatSoft), through analysis of variance (ANOVA). The statistical significance of the model was analyzed by the F test at a 5\% significance level (p-value<0.05) (Barros Neto, Bruns, \& Scarminio, 2010). The run with the highest ethanol production was submitted to an acetic fermentation by the bacterium Acetobacter aceti.

\subsection{Acetic acid fermentation}

The Acetobacter aceti cells were activated in $25 \mathrm{~mL}$ mannitol agar (MA). Its composition was D-mannitol (25 g L-1), yeast extract $\left(5 \mathrm{~g} \mathrm{~L}^{-1}\right)$, and bacteriological peptone $\left(3 \mathrm{~g} \mathrm{~L}^{-1}\right)$. The medium culture was sterilized in an autoclave for $15 \mathrm{~min}$ at $121^{\circ} \mathrm{C}$ and incubated at $32^{\circ} \mathrm{C}$ for $48 \mathrm{~h}$ at $100 \mathrm{rpm}$ in an orbital shaker.

The medium MA was activated in $250 \mathrm{~mL}$ and then incubated in an orbital shaker at $32^{\circ} \mathrm{C}$ and $100 \mathrm{rpm}$ for $24 \mathrm{~h}$. Stock cultures of acetic bacteria strains were maintained in MA medium with agar-agar $\left(15 \mathrm{~g} \mathrm{~L}^{-1}\right)$ in slant tubes for $48 \mathrm{~h}$ at $32^{\circ} \mathrm{C}$ in a microbiological growth oven and were stored in a refrigerator at $4{ }^{\circ} \mathrm{C}$.

For AA fermentation, the yeast $K$. marxianus was removed by filtration $\left(0.45 \mu \mathrm{m}\right.$ pore size, type $\left.\mathrm{MF}^{\mathrm{TM}}\right)$ before inoculation with the acetic bacteria A. aceti. AA fermentation cultures were carried out in 2-L fermenters containing $1000 \mathrm{~mL}$ of the alcoholic product (obtained from the fermentation of the CWP) and $110 \mathrm{~mL}$ of bacterial inoculum of A. aceti.

Acetic cultures were performed employing three methods: Orleans, aerated, and stirred. Assays were conducted in 5-L adapted reactors. The Orleans method was adapted from Aquarone \& Zancanaro (1983) and kept in a bacteriological oven. The aerated method was adapted from Toit, Lisjak, Marais, \& Du Toit (2006) and performed inserting oxygen microbubbles in the growth medium using a disperser near the bottom of the reactor with an airflow ratio of $1: 5 \mathrm{vvm}\left(0.8 \mathrm{~L} \mathrm{~min}^{-1}\right)$ and kept in a 
bacteriological oven. The stirred method was adapted from Talabardon, Schwitzguébel, \& Péringer (2000) and performed in an incubator with orbital stirring of $350 \mathrm{rpm}$. All assays were conducted at a fixed temperature of $32^{\circ} \mathrm{C}$, with initial $\mathrm{pH}$ between 4.85 and 5.18 for 28 days.

$\mathrm{pH}$, ethanol and organic acids production, and cellular biomass by cell dry weight were measured throughout the fermentations. $10 \mathrm{~mL}$ of liquid samples was taken with sterile syringes throughout of fermenters every 3 days.

\subsection{Analytical determination}

Yeast probiotic cellular biomass of alcoholic fermentation was analyzed using spectrophotometric methods (OD $600 \mathrm{~nm})$ at $600 \mathrm{~nm}$ wavelength, considering an equivalent of $0.507 \mathrm{~g} \mathrm{~L}^{-1}$ of dry cellular biomass of $K$. marxianus, according to the methodology of Diniz et al. (2012). Cellular biomass in terms of total cell dry weight of A. aceti was determined according to Krusong \& Tantratian (2014). The pH was monitored in a Portable Digital pH meter. Ethanol and organic acids (acetic, propionic, valeric, lactic, formic, and butyric acids) concentrations were determined by High Performance Liquid Chromatography (HPLC) (Shimadzu Prominence, model DGU-20A 5 ) equipped with refractive index detector and a Rezex ROA Organic Acid column (250 $\mathrm{mm} \times 4.6 \mathrm{~mm}$ ), a flow rate of $0.8 \mathrm{~mL} \mathrm{~min}^{-1}$, using $5 \mathrm{mM}$ sulfuric acid as eluent at $64^{\circ} \mathrm{C}$, and sample volumes of $20 \mu \mathrm{L}$ (Lazaro, Vich, Hirasawa, \& Varesche, 2012). The substrate concentration (lactose) was also measured by HPLC with refractive index detector and Rezex RSO - OLIGOSACCHARIDE $\mathrm{Ag}^{+}(4 \%)$ column (200x10 mm), a flow rate of $0.3 \mathrm{~mL} \mathrm{~min}{ }^{-1}$, using degassed water as eluent at $75^{\circ} \mathrm{C}$, and sample volumes of $20 \mu \mathrm{L}$.

\subsection{Kinetic parameters of alcoholic and acetic fermentations}

The kinetics parameters of alcoholic fermentations, analyzed based on Diniz, Rodrigues, Fietto, Passos, \& Silveira (2013), and Murari et al. (2018), to evaluate the performance of the ethanol production in the exponential growth phase, were specific growth rate $\left(\mu_{\mathrm{X}}\right)$, substrate to probiotic cellular biomass yield conversion $\left(\mathrm{Y}_{\mathrm{X} / \mathrm{S}}\right)$, ethanol to probiotic cellular biomass yield conversion $\left(\mathrm{Y}_{\mathrm{X} / \mathrm{P}}\right)$, substrate to ethanol yield conversion $\left(\mathrm{Y}_{\mathrm{P} / \mathrm{S}}\right)$, volumetric productivity of ethanol $\left(\mathrm{Q}_{\mathrm{P}}\right)$, and theoretical conversion of substrate to ethanol (n), and they were expressed, respectively, by Eqs. 2-7.

$$
\begin{aligned}
& \mu_{X}=\frac{1}{X} \cdot \frac{d X}{d t}\left(h^{-1}\right) \\
& Y_{X / S}=\frac{X_{f}-X_{0}}{S_{t}-S_{f}}\left(g^{-1}\right) \\
& Y_{X / P}=\frac{X_{f}-X_{0}}{E_{t}-E_{f}}\left(g^{-1}\right) \\
& Y_{P / S}=\frac{E_{f}-E_{0}}{S_{t}-S_{f}}\left(g^{-1}\right) \\
& Q_{P}=\frac{E_{f}-E_{0}}{t_{f}}\left(g^{-1} h^{-1}\right) \\
& n=\frac{\left(E_{f}-E_{0}\right) * 100}{\left(S_{t}-S_{f}\right) * 0.5368}(\%)
\end{aligned}
$$

Where: 
$\mathrm{X}_{0}=$ initial biomass concentration $\left(\mathrm{g} \mathrm{L}^{-1}\right), \mathrm{X}_{\mathrm{f}}=$ final biomass concentration $\left(\mathrm{g} \mathrm{L}^{-1}\right), \mathrm{S}_{\mathrm{t}}=$ total substrate concentration $\left(\mathrm{g} \mathrm{L}^{-1}\right)$, $\mathrm{S}_{\mathrm{f}}=$ final substrate concentration $\left(\mathrm{g} \mathrm{L}^{-1}\right), \mathrm{E}_{0}=$ initial ethanol product concentration $\left(\mathrm{g} \mathrm{L}^{-1}\right), \mathrm{E}_{\mathrm{f}}=$ final ethanol product concentration $\left(\mathrm{g} \mathrm{L}^{-1}\right), \mathrm{E}_{\mathrm{t}}=$ total ethanol product concentration $\left(\mathrm{g} \mathrm{L}^{-1}\right), \mathrm{t}_{\mathrm{f}}=$ final fermentation time $(\mathrm{h})$, and 0.5368 is the mass conversion.

For acetic fermentation, the kinetic parameters were volumetric productivity of $A A\left(Q_{A c}\right)$ and yield $\left(Y_{A c}\right)$ as proposed by Ferreyra, Schvab, Davies, Gerard, \& Hours (2012), and total concentration yield ( $\left.\mathrm{Y}_{\mathrm{CT}}\right)$ based on Spinosa et al. (2015), and given, respectively, by Eqs. 8-10.

$$
\begin{gathered}
\mathrm{Q}_{\mathrm{Ac}}=\frac{\left(\mathrm{Ac}_{\mathrm{f}}-\mathrm{Ac}_{0}\right)}{\mathrm{t}_{\mathrm{f}}}\left(\mathrm{g} \mathrm{L}^{-1} \mathrm{~h}^{-1}\right) \\
\mathrm{Y}_{\mathrm{Ac}}=\frac{\left(\mathrm{Ac}_{\mathrm{f}}-\mathrm{Ac}_{0}\right)}{\mathrm{E}_{0}} * 100(\%) \\
\mathrm{Y}_{\mathrm{CT}}=\frac{\left(\mathrm{E}_{\mathrm{f}}-\mathrm{Ac}_{\mathrm{f}}\right)}{\left(\mathrm{E}_{0}-\mathrm{Ac}_{0}\right)}(\%)
\end{gathered}
$$

Where:

$\mathrm{Ac}_{0}=$ initial acetic acid product concentration $\left(\mathrm{g} \mathrm{L}^{-1}\right)$, and $\mathrm{Ac}_{\mathrm{f}}=$ final acetic acid product concentration

\subsection{Total chemical and biochemical oxygen demand removal}

COD and BOD removal were performed according to the procedures described in Wehr \& Frank (2004).

\section{Results}

\subsection{Statistical model and response surfaces of alcoholic fermentations}

The results of the $2^{3}$ factorial design investigation of the ideal conditions (temperature, $\mathrm{pH}$, and lactose concentration) to maximize ethanol production from CWP are summarized in Table 1. The ANOVA results are shown in Table 2.

Table 1. $2^{3}$ factorial design (actual and coded values) for ethanol [Y] production in $45 \mathrm{~h}$ of fermentation

\begin{tabular}{ccccc}
\hline \multirow{2}{*}{ Run } & \multicolumn{3}{c}{ Independent variables } & Response variable \\
\cline { 2 - 5 } & Temperature $\left({ }^{\circ} \mathrm{C}\right)\left[\mathrm{X}_{1}\right]$ & $\mathrm{pH}\left[\mathrm{X}_{2}\right]$ & Lactose $\left(\mathrm{g} \mathrm{L}^{-1}\right)\left[\mathrm{X}_{3}\right]$ & Ethanol $\left(\mathrm{g} \mathrm{L}^{-1}\right)[\mathrm{Y}]$ \\
\hline 1 & $29(-1)$ & $4.5(-1)$ & $88(-1)$ & $47.18 \pm 0.05$ \\
2 & $45(+1)$ & $4.5(-1)$ & $88(-1)$ & $23.37 \pm 0.07$ \\
3 & $29(-1)$ & $6.5(+1)$ & $88(-1)$ & $33.33 \pm 0.03$ \\
4 & $45(+1)$ & $6.5(+1)$ & $88(-1)$ & $19.59 \pm 0.09$ \\
5 & $29(-1)$ & $4.5(-1)$ & $264(+1)$ & $42.80 \pm 0.08$ \\
6 & $45(+1)$ & $4.5(-1)$ & $264(+1)$ & $19.04 \pm 0.04$ \\
7 & $29(-1)$ & $6.5(+1)$ & $264(+1)$ & $29.00 \pm 0.05$ \\
8 & $45(+1)$ & $6.5(+1)$ & $264(+1)$ & $12.80 \pm 0.06$ \\
9 & $37(0)$ & $5.5(0)$ & $176(0)$ & $37.53 \pm 0.06$ \\
10 & $37(0)$ & $5.5(0)$ & $176(0)$ & $37.28 \pm 0.08$ \\
11 & $37(0)$ & $5.5(0)$ & $176(0)$ & $37.50 \pm 0.07$ \\
\hline
\end{tabular}


Table 2. Analysis of variance for the $2^{3}$ factorial design for the response variable ethanol (Y).

\begin{tabular}{ccccccc}
\hline $\begin{array}{c}\text { Response } \\
\text { variable }\end{array}$ & Variance & $\begin{array}{c}\text { Sum-of- } \\
\text { squares }\end{array}$ & $\begin{array}{c}\text { Degrees of } \\
\text { freedom }\end{array}$ & $\begin{array}{c}\text { Mean } \\
\text { squares }\end{array}$ & $\begin{array}{c}\text { F- } \\
\text { value }\end{array}$ & $\begin{array}{c}\text { Determination } \\
\text { coefficient }\left(\mathbf{R}^{2}\right)\end{array}$ \\
\hline \multirow{2}{*}{$(\mathrm{Y})$} & Model & 5214.12 & 6 & 869.02 & 10.13 & 0.85 \\
& Error & 33.17 & 4 & 85.79 & & \\
& Total & 5557.29 & & & & \\
\hline
\end{tabular}

Source: Authors.

The levels of the independent variables investigated by the $2^{3}$ factorial experimental design are in Table 1 , which shows the real and the coded factors for temperature $\left({ }^{\circ} \mathrm{C}\right), \mathrm{pH}$, and lactose concentration $\left(\mathrm{g} \mathrm{L}^{-1}\right)$ present in the CWP, as well as the response variable ethanol $\left(\mathrm{g} \mathrm{L}^{-1}\right)$. While Table 2 exhibits the results of the experimental design for the analysis of variance (ANOVA) of the response variable of the research.

Ethanol was produced at all evaluated conditions, evidencing the ability of this yeast to bioconvert lactose and other nutrients present in CWP into products of interest and with added value. This advantageous characteristic in the bioproducts production by $K$. marxianus was also observed by other authors (Diniz et al., 2012; Murari et al., 2018).

From the evaluated conditions, the maximum ethanol concentration $\left(47.18 \pm 0.05 \mathrm{~g} \mathrm{~L}^{-1}\right)$ was achieved at $29^{\circ} \mathrm{C}$, $\mathrm{pH} 4.5$, and $88 \mathrm{~g} \mathrm{~L}^{-1}$ lactose (run 1), followed by run $5\left(42.80 \pm 0.08 \mathrm{~g} \mathrm{~L}^{-1}\right)$ at $29{ }^{\circ} \mathrm{C}, \mathrm{pH} 4.5$, and $264 \mathrm{~g} \mathrm{~L}^{-1}$ lactose, while the lowest production was at run $8\left(12.80 \pm 0.06 \mathrm{~g} \mathrm{~L}^{-1}\right)$ in the condition of temperature $45^{\circ} \mathrm{C}$, $\mathrm{pH} 6.5$, and $264 \mathrm{~g} \mathrm{~L}^{-1}$.

The calculated $F$ value $($ Table 2$)$ is $\mathrm{Fc}_{(6 ; 4 ; 0.05)}=10.13$, higher than the tabulated $\mathrm{F}$ value $\left(\mathrm{F}_{\mathrm{tab} 6 ; 4 ; 0.05}=6.16\right)$ at a confidence interval of $95 \%$ This means that the regression model was statistically significant for the alcoholic fermentation performance for ethanol production from CWP, thus indicating that the model well fitted the experimental data (Barros Neto, Bruns, \& Scarminio, 2010). Another indication that the model is valid and reliable is the determination coefficient $\left(\mathrm{R}_{2}\right)$ of 0.85 , which means that the model can explain 85\% of the response variability (Murari et al., 2019). Therefore, ethanol production (Y) was modeled by Equation (9) where $\mathrm{X}_{1}$ is the temperature, $\mathrm{X}_{2}$ the $\mathrm{pH}$, and $\mathrm{X}_{3}$ the lactose concentration in their coded forms.

$$
Y=34.98-32.17 X_{1}-23.76 X_{2}-19.75 X_{3}+17.03 X_{1}: X_{2}+11.47 X_{1}: X_{3}+14.02 X_{2}: X_{3}(9)
$$

The contour plot for the independent variables, lactose concentration, temperature, and $\mathrm{pH}$ for ethanol production by $K$. marxianus CCT 4086 and the predictive ability of the model (predicted and observed values) are presented in Figure 1 (a-d), and Figure 2 shows the Pareto chart for ethanol. 
Figure 1. Contour-plot for the independent variables: concentration of lactose, temperature, and pH for ethanol production by Kluyveromyces marxianus CCT 4086: (a) pH and temperature; (b) lactose and temperature, (c) lactose and pH, and (d) Predictive ability of the model: predicted and observed values for ethanol production

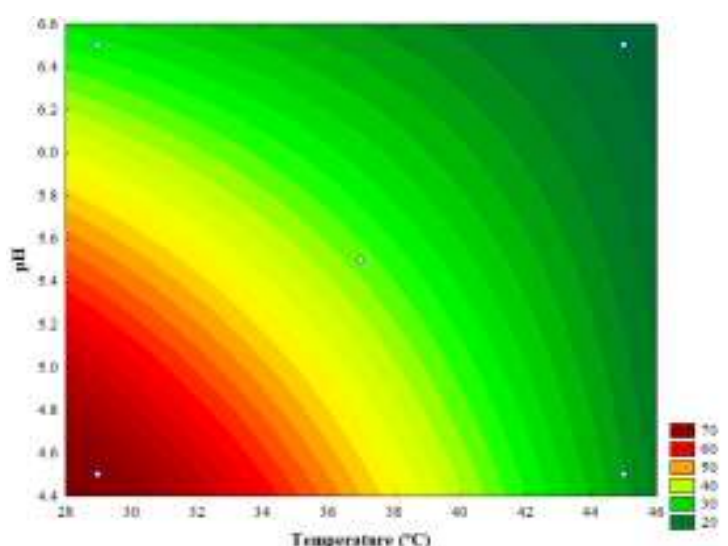

(a)

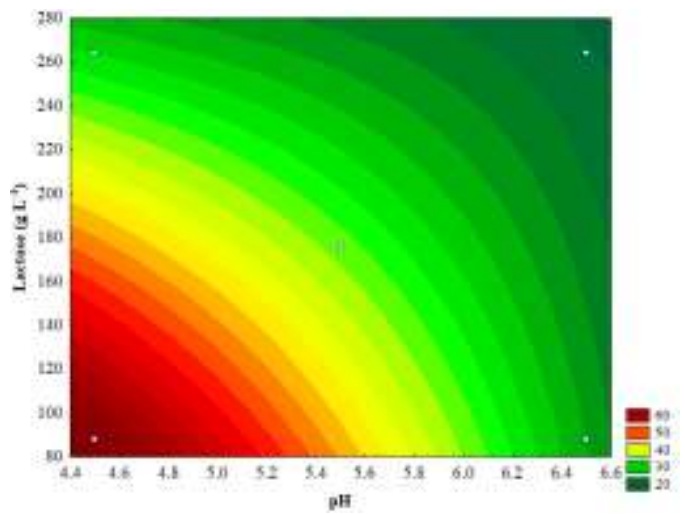

(c)

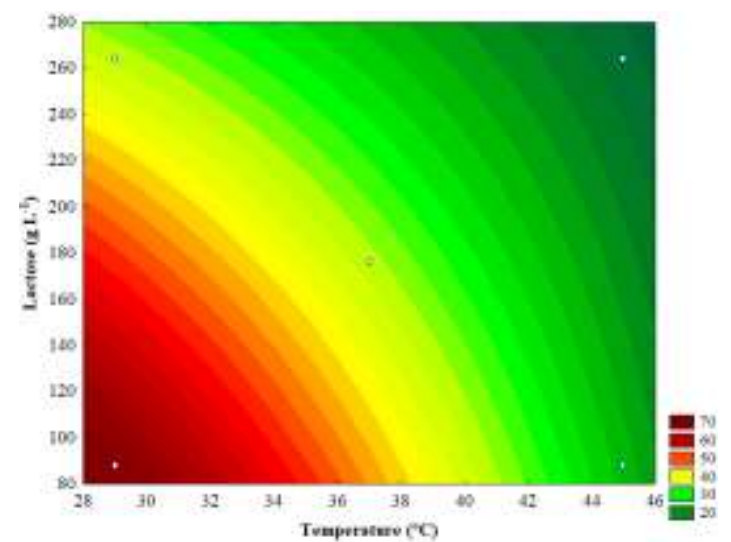

(b)

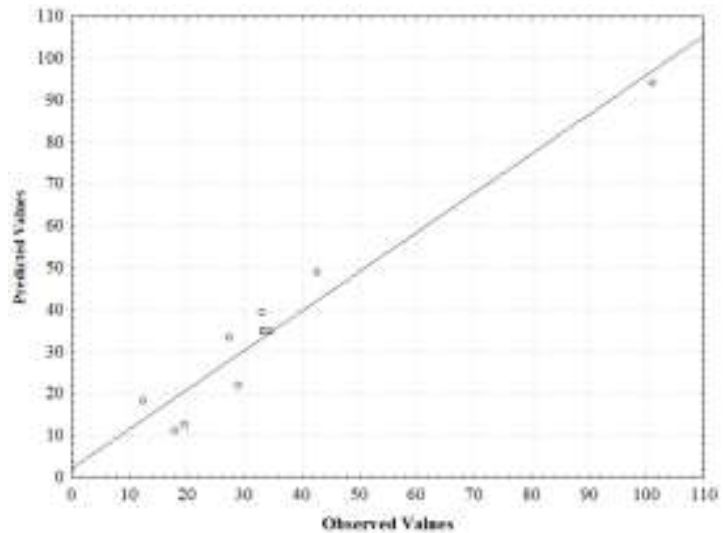

(d)

Source: Authors.

Figure 2. Pareto chart for ethanol production (Y) by Kluyveromyces marxianus CCT 4086.

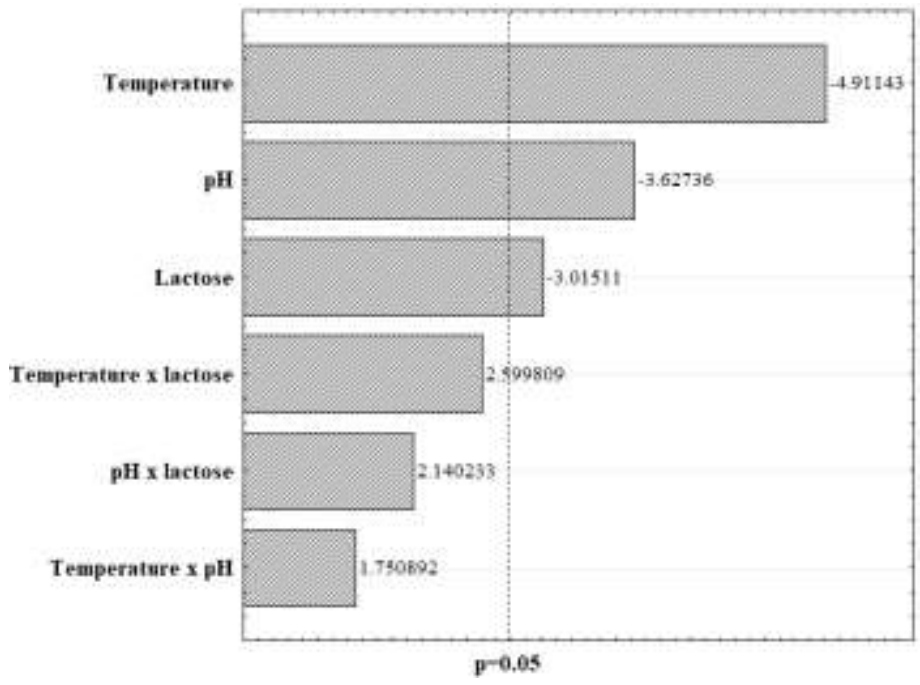

Source: Authors. 
Figure 1 shows the contour plot for the independent variables for ethanol production, thus, Figure 1 (a) evaluates the relationship between $\mathrm{pH}$ and temperature, while Figure 1 (b) analyzes the interaction between lactose concentration and temperature, and Figure 1 (c) explores the lactose concentration regarding the $\mathrm{pH}$, all aiming at the maximum conversion of CWP into ethanol by the yeast $K$. marxianus. Lastly, Figure 1 (d) demonstrates the ethanol formation through the predictive capacity of the model regarding the predicted and observed values. And Figure 2 represents the absolute values of the effects to produce ethanol from the interaction between the independent variables investigated through the Pareto chart.

Figure 1 (d) shows the predictive ability of the model, evidencing that there is a good correlation between the observed and the predicted values. Besides, through the Pareto chart (Figure 2), the independent factors and their interactions that were significant to produce ethanol could be identified (Figure 2); those were: temperature $\left(\mathrm{X}_{1}\right), \mathrm{pH}\left(\mathrm{X}_{2}\right)$, and lactose concentration $\left(\mathrm{X}_{3}\right)$, and all of them were negatively significant. This indicates that the factors $\left(\mathrm{X}_{1}, \mathrm{X}_{2}\right.$, and $\left.\mathrm{X}_{3}\right)$ influenced the fermentative metabolism of $K$. marxianus and that at lower values of them, there is higher production. Therefore, to maximize ethanol production from CWP, lower temperatures, pHs, and lactose concentrations (CWP), 28-30 ${ }^{\circ} \mathrm{C}, 4.4-4.8$, and 80-130 g $\mathrm{L}^{-1}$, respectively, are indicated.

\subsection{Ethanol production kinetics of alcoholic fermentations}

The kinetics profiles of the production of ethanol $\left(\mathrm{g} \mathrm{L}^{-1}\right)$, probiotic cellular biomass $\left(\mathrm{g} \mathrm{L}^{-1}\right)$, lactose concentration $\left(\mathrm{g} \mathrm{L}^{-1}\right)$, and $\mathrm{pH}$, during the $45 \mathrm{~h}$ of alcoholic fermentation for the runs of the $2^{3}$ factorial design are illustrated in Figure 3 . Table 3 shows the results of the kinetic parameters.

Figure 3. Kinetics profile of the production of ethanol $\left(\mathrm{g} \mathrm{L}^{-1}\right)(\bullet)$, cellular biomass $\left(\mathrm{g} \mathrm{L}^{-1}\right)(\bullet)$, lactose $\left(\mathrm{g} \mathrm{L}^{-1}\right)(0)$, and $\mathrm{pH}(\boldsymbol{\nabla})$ in $45 \mathrm{~h}$ of fermentation for the runs of the $2^{3}$ factorial design of experiments by Kluyveromyces marxianus CCT 4086, (a) run 1 , (b) run 2, (c) run 3, (d) run 4, (e) run 5, (f) run 6, (g) run 7, (h) run 8, (i) run 9, (j) run 10, and (k) run 11 of the $2^{3}$ factorial experimental design.

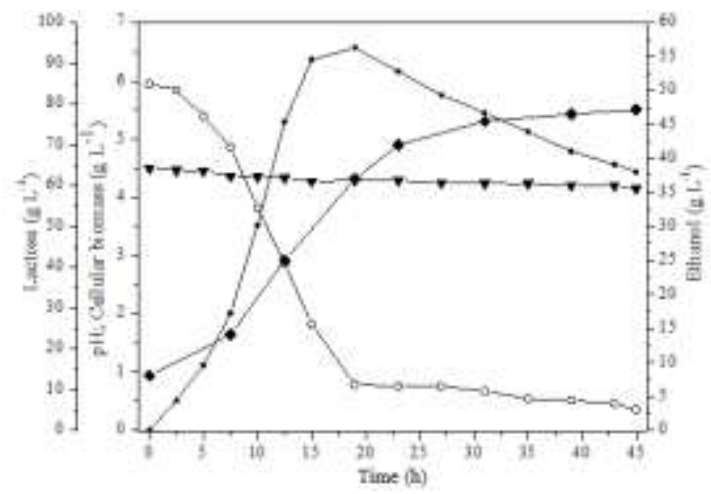

(a)

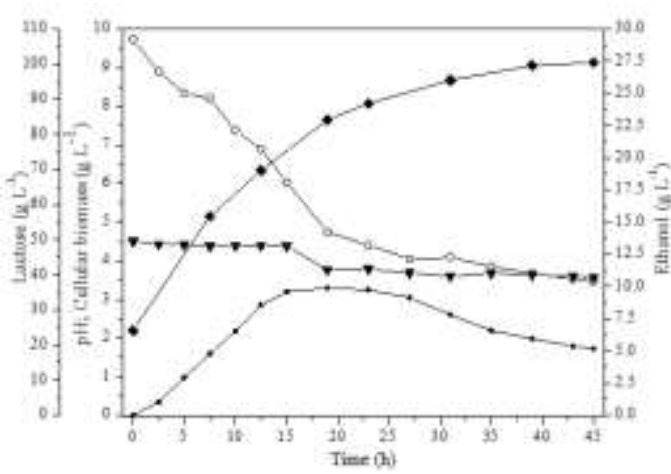

(b) 
Research, Society and Development, v. 10, n. 13, e212101321082, 2021

(CC BY 4.0) | ISSN 2525-3409 | DOI: http://dx.doi.org/10.33448/rsd-v10i13.21082

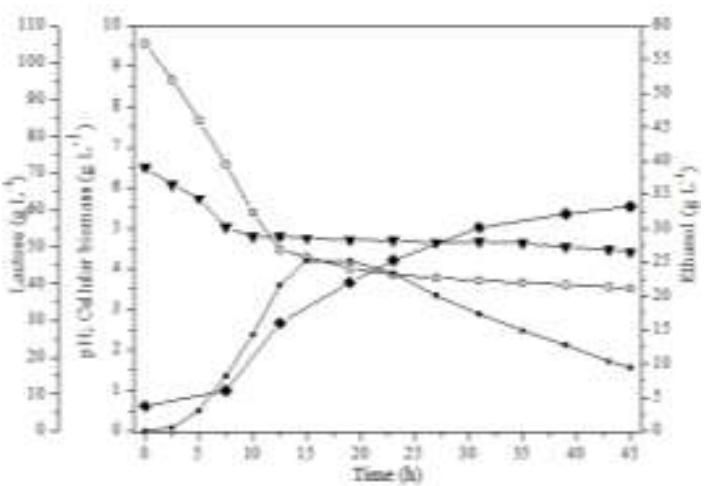

(c)

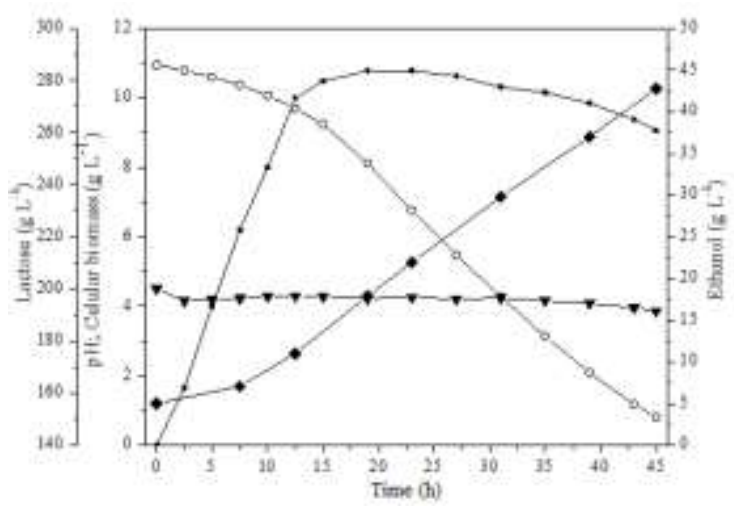

(e)

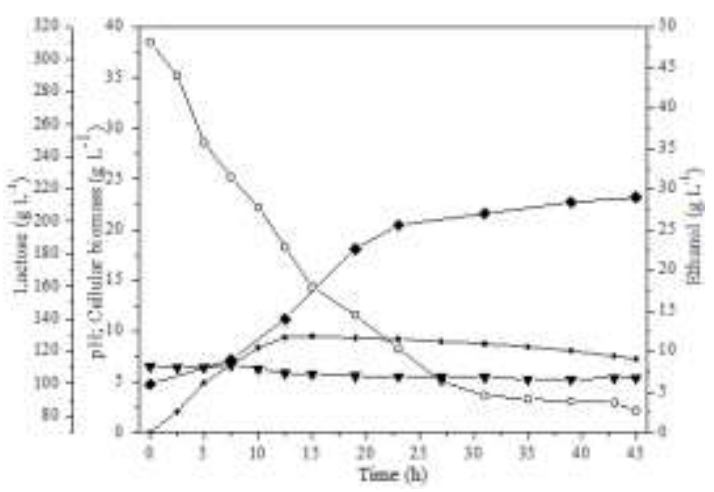

$(\mathrm{g})$

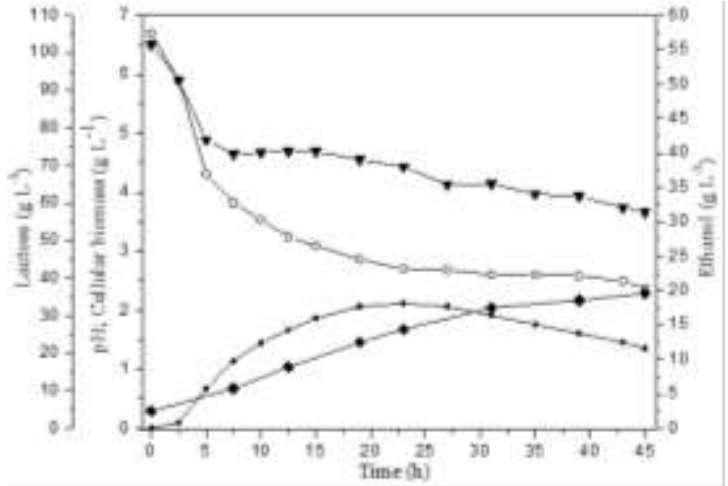

(d)

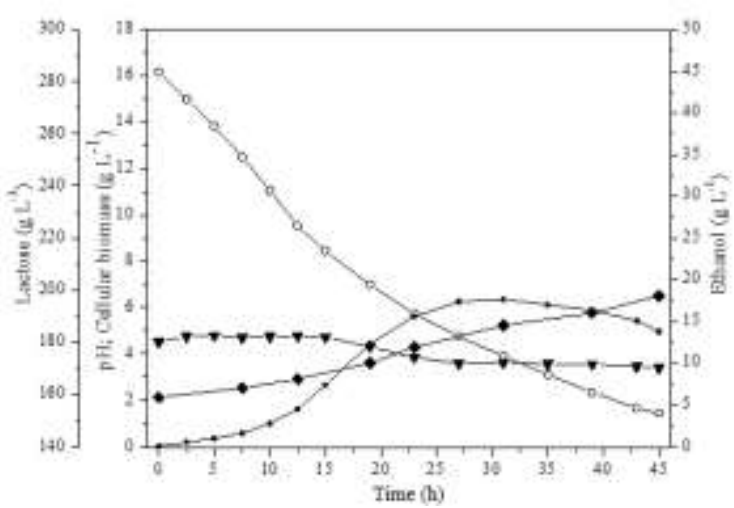

(f)

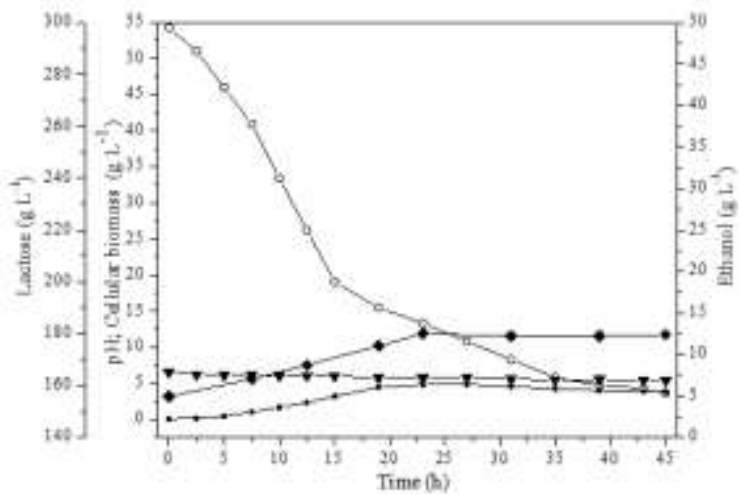

(h) 


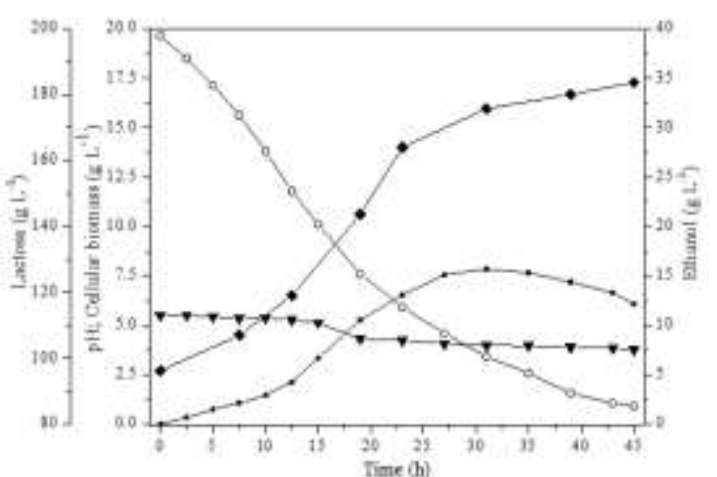

(i)

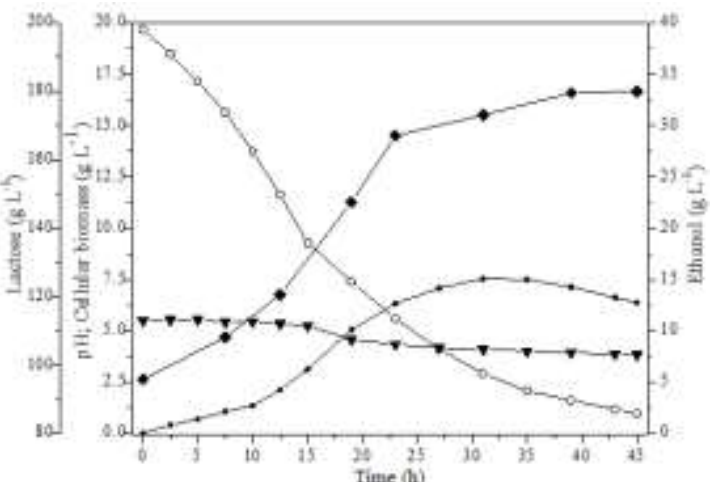

(j)

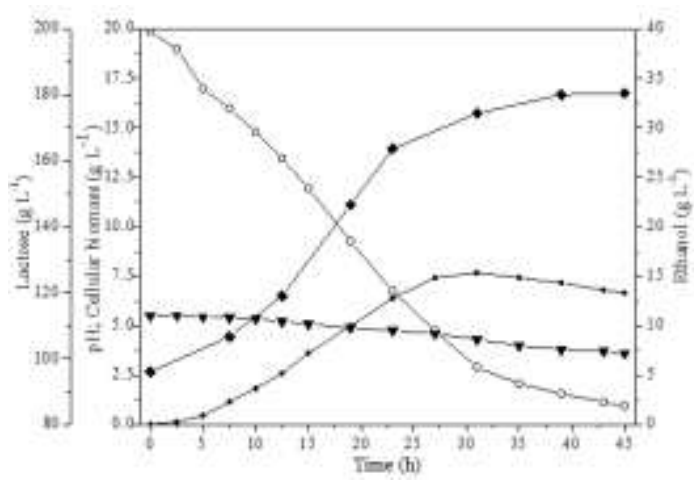

$(\mathrm{k})$

Source: Authors.

Table 3. Fermentation kinetic parameters obtained in the fermentation of the cheese whey permeate by K. marxianus CCT 4086.

\begin{tabular}{clcccccc}
\hline Run & $\boldsymbol{\mu}_{\mathbf{X}}\left(\mathbf{h}^{-\mathbf{1}}\right)$ & $\mathbf{Y}_{\mathbf{X} / \mathbf{s}}\left(\mathbf{g ~ g}^{-\mathbf{1}}\right)$ & $\mathbf{Y}_{\mathbf{X} / \mathbf{P}}\left(\mathbf{g ~ g}^{-\mathbf{1}}\right)$ & $\mathbf{Y}_{\mathbf{P} / \mathbf{S}}\left(\mathbf{g ~ g}^{-\mathbf{1}}\right)$ & $\mathbf{Q}_{\mathbf{P}}\left(\mathbf{g ~ L}^{-1} \mathbf{h}^{-1}\right)$ & $\mathbf{n}(\boldsymbol{\%})$ & Time (h) \\
\hline 1 & 0.44 & 0.09 & 0.23 & 0.39 & 1.52 & 72.83 & 19 \\
2 & 0.24 & 0.06 & 0.20 & 0.30 & 0.86 & 55.59 & 19 \\
3 & 0.41 & 0.06 & 0.21 & 0.30 & 0.96 & 55.78 & 19 \\
4 & 0.11 & 0.02 & 0.14 & 0.18 & 0.53 & 32.74 & 19 \\
5 & 0.82 & 0.29 & 1.62 & 0.18 & 0.68 & 32.69 & 19 \\
6 & 0.32 & 0.08 & 0.39 & 0.20 & 0.86 & 37.16 & 31 \\
7 & 0.72 & 0.05 & 0.42 & 0.12 & 0.68 & 23.21 & 31 \\
8 & 0.27 & 0.05 & 0.73 & 0.07 & 0.29 & 12.92 & 23 \\
9 & 0.37 & 0.08 & 0.30 & 0.27 & 0.85 & 50.59 & 31 \\
10 & 0.36 & 0.08 & 0.29 & 0.26 & 0.83 & 47.66 & 31 \\
11 & 0.34 & 0.08 & 0.29 & 0.26 & 0.84 & 47.63 & 31 \\
\hline
\end{tabular}

$\mu_{\mathrm{X}}$ : specific growth rate; $\mathrm{Y}_{\mathrm{X} / \mathrm{S}}$ : substrate to probiotic cellular biomass yield conversion; $\mathrm{Y}_{\mathrm{X} / \mathrm{P}}$ : ethanol to probiotic cellular biomass yield conversion; $\mathrm{Y}_{\mathrm{P} / \mathrm{S}}$ : substrate to ethanol yield conversion; $\mathrm{Q}_{\mathrm{P}}$ : volumetric productivity of ethanol; $\mathrm{n}$ : theoretical conversion of substrate to ethanol.

Source: Authors. 
Table 3 describes the kinetic parameters used to evaluate the efficiency of a fermentative process. The specific growth rate $\left(\mu_{\mathrm{X}}\right)$ is related to the cellular doubling time, that is, higher values promote lower cellular doubling times, consequently, the nutrients conversion process by the microorganism will become more favorable. The conversion factors $\left(\mathrm{Y}_{\mathrm{X} / \mathrm{S}} ; \mathrm{Y}_{\mathrm{X} / \mathrm{P}} ; \mathrm{Y}_{\mathrm{P} / \mathrm{S}}\right)$ evaluate how the carbon source was used by the microorganism to grow, cellular maintenance, and production of the metabolite of interest. While productivity and efficiency $\left(Q_{P} ; n\right)$ show in which condition the alcoholic fermentation process was more efficient, that is, which one will provide the bigger profitability and that will be more favorable to an industrial application.

As mentioned, ethanol reached a maximum concentration $\left(47.18 \pm 0.05 \mathrm{~g} \mathrm{~L}^{-1}\right)$ at run 1 which also presented the highest productivity $\left(1.52 \mathrm{~g} \mathrm{~L}^{-1} \mathrm{~h}^{-1}\right)$, yield $(72.83 \%)$, and substrate to ethanol yield conversion coefficient $\left(0.39 \mathrm{~g} \mathrm{~g}^{-1}\right)$ in $19 \mathrm{~h}$ of fermentation, higher values than the ones obtained by Murari et al. (2018) $50 \mathrm{~g} \mathrm{~L}^{-1}$ of lactose, $\mathrm{pH} 4.6,100 \mathrm{rpm}$, and $30{ }^{\circ} \mathrm{C}$ in 12 $\mathrm{h}\left(\mathrm{Q}_{\mathrm{P}}=0.66 \mathrm{~g} \mathrm{~L}^{-1} \mathrm{~h}^{-1}, \mathrm{n}=44.37 \%\right.$, and $\left.\mathrm{Y}_{\mathrm{P} / \mathrm{S}}=0.24 \mathrm{~g} \mathrm{~g}^{-1}\right)$ with the highest ethanol production of $8.90 \mathrm{~g} \mathrm{~L}^{-1}$ at $18 \mathrm{~h}$.

The highest production of the probiotic cellular biomass $\left(10.80 \pm 0.24 \mathrm{~g} \mathrm{~L}^{-1}\right)$ was at run 5 at $19 \mathrm{~h}$ of the process $\left(29^{\circ} \mathrm{C}\right.$, $\mathrm{pH} 4.5,264 \mathrm{~g} \mathrm{~L}^{-1}$ of lactose). At this time, the substrate to probiotic cellular biomass yield conversion was $0.29 \mathrm{~g} \mathrm{~g}^{-1}$, ethanol to probiotic cellular biomass yield conversion was $1.62 \mathrm{~g} \mathrm{~g}^{-1}$, and specific growth rate was $0.82 \mathrm{~h}^{-1}$, also a higher value than the obtained by Murari et al. (2018) $\left(0.25 \mathrm{~h}^{-1}\right)$.

In the kinetics profiles (Figure 3), the medium $\mathrm{pH}$ decreased until around 4.0, posteriorly stabilizing in all runs. Alcoholic fermentation is an anaerobic process of transformation of sugars into ethanol and carbon dioxide as the main products, and secondary compounds such as glycerol, AA, succinic acid, and lactic acid, among others, which are responsible for decreasing the medium pH (Nagodawithana \& Steinkraus, 1976).

The highest $\mathrm{pH}$ decrease was observed in runs 3, 4, 7-11, in which the initial $\mathrm{pH}$ was higher (5.5-6.5), which can also mean that those conditions enabled not only ethanol production but also secondary metabolites, which is undesirable when ethanol is the main product of interest (Güneser, Karagül-Yüceer, Wilkowska, \& Kregiel, 2016). Organic acids were identified in the runs, with concentrations in the range of: 0.5 to $5 \mathrm{~g} \mathrm{~L}^{-1}$ (AA), 1 to $3 \mathrm{~g} \mathrm{~L}^{-1}$ (propionic), 0.5 to $2.5 \mathrm{~g} \mathrm{~L}^{-1}$ (valeric), 0.5 to $6 \mathrm{~g} \mathrm{~L}^{-}$ ${ }^{1}$ (lactic), 0.5 to $3 \mathrm{~g} \mathrm{~L}^{-1}$ (formic), and 0.5 to $2.3 \mathrm{~g} \mathrm{~L}^{-1}$ (butyric).

The runs conducted with a lactose concentration of $264 \mathrm{~g} \mathrm{~L}^{-1}$ were more favorable for probiotic cellular biomass production than for ethanol production, as observed in runs 5 and $7\left(29{ }^{\circ} \mathrm{C}\right.$ and $264 \mathrm{~g} \mathrm{~L}^{-1}$ of lactose), a higher probiotic cellular biomass was obtained, being $10.80 \pm 0.24 \mathrm{~g} \mathrm{~L}^{-1}(19 \mathrm{~h})$, and $9.50 \pm 0.44 \mathrm{~g} \mathrm{~L}^{-1}$ in $15 \mathrm{~h}$, respectively, only differing regarding $\mathrm{pH}(4.5$ in run 5 and 6.5 in run 7). The same conclusion, that high lactose concentrations favor biomass production, is observed for the runs performed in the center point, with mean biomass of $7.68 \pm 0.16 \mathrm{~g} \mathrm{~L}^{-1}(31 \mathrm{~h})$.

Regarding temperature, the behavior of achieving the highest ethanol at lower temperatures, around $28^{\circ} \mathrm{C}$, was also observed by Zoppellari and Bardi (2013), since the highest ethanol production was at $29^{\circ} \mathrm{C}$ (run 1). Other authors using dairy material from different sources and yeasts from the genus Kluyveromyces, obtained higher ethanol productions when operating at temperatures in the range of $30-32^{\circ} \mathrm{C}$ (Ghanadzadeh \& Ghorbanpour, 2012).

Considering the ethanol to probiotic cellular biomass yield conversion coefficient $\left(\mathrm{Y}_{\mathrm{X} / \mathrm{P}}\right)$ and substrate to probiotic cellular biomass yield conversion $\left(\mathrm{Y}_{\mathrm{X} / \mathrm{S}}\right)$ (Table 3), there was a conversion of $1.62 \mathrm{~g} \mathrm{~g}^{-1}$ of ethanol into probiotic cellular biomass and substrate to probiotic cellular biomass of $0.29 \mathrm{~g} \mathrm{~g}^{-1}$ for run 5 in $19 \mathrm{~h}$. While run $7\left(29{ }^{\circ} \mathrm{C}, \mathrm{pH} 6.5,264 \mathrm{~g} \mathrm{~L}^{-1}\right)$ achieved high values of $\mu_{\mathrm{X}}=0.72 \mathrm{~h}^{-1}$, condition with low ethanol production and high probiotic cellular biomass production $\left(20 \mathrm{~g} \mathrm{~L} \mathrm{~L}^{-1}, 9.50 \pm 0.44\right.$ $\mathrm{g} \mathrm{L}^{-1}$ in $15 \mathrm{~h}$, respectively).

During the alcoholic fermentation, prebiotic GOS could also be identified, with production between 4.7 to $20.3 \mathrm{~g} \mathrm{~L}^{-1}$ in $45 \mathrm{~h}$ of fermentation (maximum production in run 7 at $29^{\circ} \mathrm{C}, \mathrm{pH} 6.5,264 \mathrm{~g} \mathrm{~L}^{-1}$ of lactose), being higher in the runs with the highest lactose concentration (runs 5-8). This happens because the yeast $K$. marxianus produces the enzyme that converts the 
lactose from the CWP into monosaccharides: glucose and galactose by the transgalactosylation reaction of lactose in the reaction medium with GOS formation using the enzyme from K. marxianus (Padilla et al., 2015). GOS is a prebiotic product that can be applied in the food industry, as a fiber source, sweetener, weight loss agents, food supplements, and other applications with added value.

The use of the raw material CWP and K. marxianus CCT4086 in biotechnological processes is noted to favor the production of different metabolites of interest since it does not only produce ethanol, but also enables the formation of secondary products such as organics acids (acetic, propionic, valeric, lactic, formic, and butyric), besides GOS and probiotic cellular biomass, products that can be recovered before performing the acetic fermentation, for applications in several industrial segments, such as food, animal feed, supplements, chemical industry, among others.

\subsection{Acetic fermentation oxidation}

The ethanol obtained in the condition of maximum production $\left(47.18 \pm 0.05 \mathrm{~g} \mathrm{~L}^{-1}\right)$ at $29^{\circ} \mathrm{C}, \mathrm{pH} 4.5$, and $88 \mathrm{~g} \mathrm{~L}^{-1}$ lactose (run 1) was used in the acetic fermentation stage to produce vinegar with the bacterium Acetobacter aceti CCT 2565 by three acetic methods: Orleans method, aerated and stirred for 28 days. Figure 4 shows the ethanol consumption and AA production during vinegar making (Runs 12 - 14), and Table 4 shows the results for the kinetic parameters for the acetic fermentation oxidation. 
Figure 4. Kinetics profile of the production of acetic acid by Acetobacter aceti CCT 2565, by (a) Orleans Method run 12, (b) Stirred Method run 13, and (c) Aerated Method run 14; acetic acid (g L-1) (•); ethanol concentration (g L-1) ( $\nabla$ ), cellular biomass $(\square)$, and $\mathrm{pH}(\mathrm{O})$

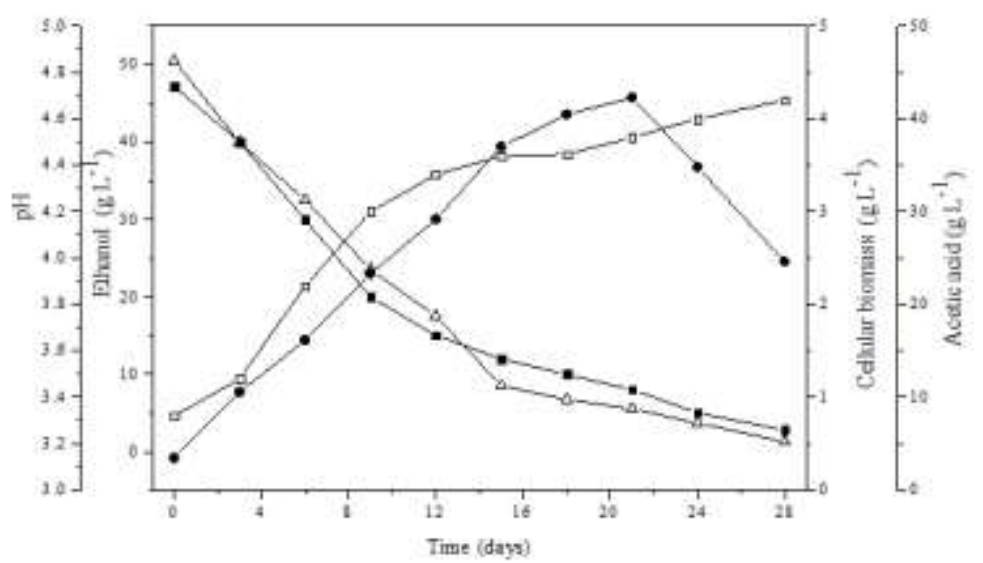

(a)

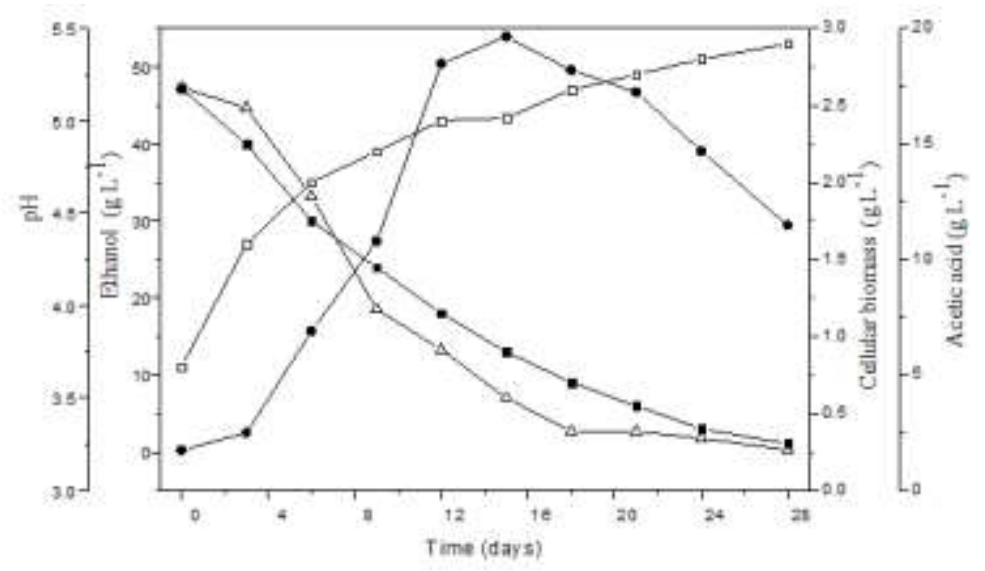

(b)

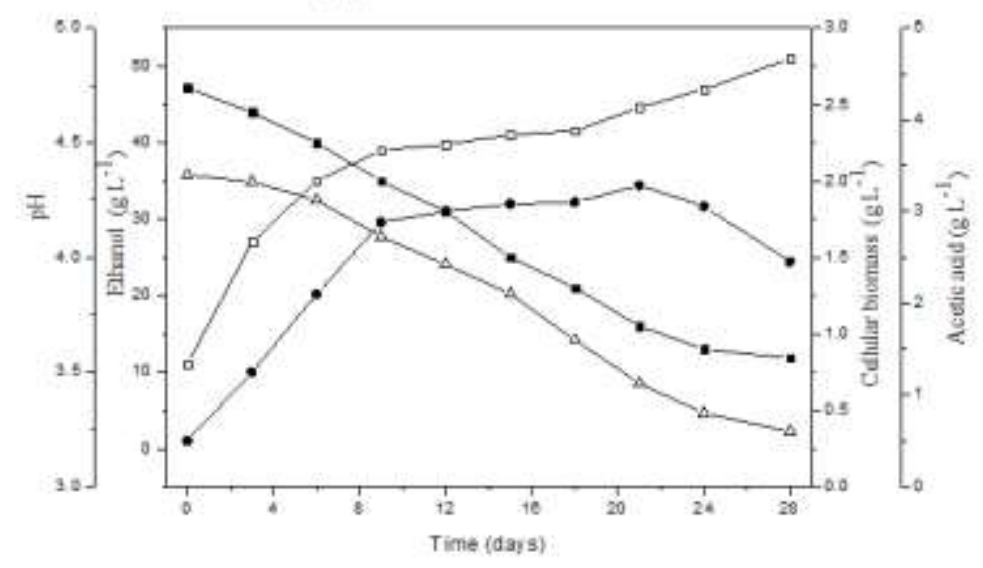

(c)

Source: Authors. 
Table 4. Maximum production of acetic acid and kinetic parameters obtained by A. aceti CCT 2565.

\begin{tabular}{ccccccccc}
\hline Run & $\begin{array}{c}\text { Acetic acid } \\
\left(\mathbf{g ~ L ~}^{-1}\right)\end{array}$ & $\begin{array}{c}\text { Time } \\
(\mathbf{d a y s})\end{array}$ & $\begin{array}{c}\mathbf{Y}_{\mathbf{A c}} \\
(\boldsymbol{\%})\end{array}$ & $\begin{array}{c}\text { Time } \\
(\mathbf{d a y s})\end{array}$ & $\mathbf{Y}_{\mathbf{C T}}(\boldsymbol{\%})$ & $\begin{array}{c}\text { Time } \\
(\mathbf{d a y s})\end{array}$ & $\begin{array}{c}\mathbf{Q}_{\text {Ac }} \\
\left(\mathbf{g ~ L}^{-\mathbf{1}} \mathbf{h}^{\mathbf{1}}\right)\end{array}$ & $\begin{array}{c}\text { Time } \\
(\mathbf{d a y s})\end{array}$ \\
\hline 12 & 42.30 & 21 & 91.18 & 18 & 1.10 & 15 & 0.11 & 15 \\
13 & 19.64 & 15 & 37.95 & 15 & 1.05 & 12 & 0.11 & 12 \\
14 & 3.29 & 21 & 5.9 & 21 & 0.89 & 12 & 0.01 & 9 \\
\hline
\end{tabular}

$\mathrm{Y}_{\mathrm{Ac}}$ : acetic fermentation yield conversion; $\mathrm{Y}_{\mathrm{CT}}$ : total concentration yield; $\mathrm{Q}_{\mathrm{Ac}}$ : volumetric productivity of acetic acid. Source: Authors.

Figure 4 demonstrates the kinetic profiles of the bacterium A. aceti for cellular growth, AA production, ethanol consumption, and $\mathrm{pH}$ change during 28 days of the fermentative process for the different methods of AA production used in this study, Orleans Method (run 12), Stirred Method (run 13), and Aerated Method (run 14). As well as in Figure 3, the microbial growth phases are observed, and also the production of the metabolite of interest, the AA, which is associated with the growth and conditioned to the nutrient availability, ethanol. Table 4 shows the factors (acetic fermentation yield conversion $\left(\mathrm{Y}_{\mathrm{Ac}}\right)$, total concentration yield $\left(\mathrm{Y}_{\mathrm{CT}}\right)$, and volumetric productivity of $\left.\mathrm{AA}\left(\mathrm{Q}_{\mathrm{Ac}}\right)\right)$ and their values used to evaluate the efficiency of the fermentative process and determine the most favorable condition to be implemented in an industrial process.

The maximum concentration of AA was $42.30 \pm 0.08 \mathrm{~g} \mathrm{~L}^{-1}$, achieved using the Orleans method (run 12) at $32^{\circ} \mathrm{C}$ in 20 days of production, with a residual ethanol concentration of $8.04 \pm 0.05 \mathrm{~g} \mathrm{~L}^{-1}$ and final $\mathrm{pH}$ of 3.02 .

After 20 days, a decrease in the AA production is noted (Figure 4-run 12 Orleans method), caused due to total depletion of ethanol and too low $\mathrm{pH}$. The medium $\mathrm{pH}$ is verified to be gradually acidifying during the bioprocess (initial $\mathrm{pH} 4.85$ and after 28 days, 3.22). During ethanol oxidation into AA, there may be an accumulation of acetate and consequently excessive acidification of the extracellular $\mathrm{pH}$, which may stress the Acetobacter species, directly influencing negatively the AA generation (Nakano, Fukaya, \& Horinouchi, 2006). Or still, a higher production of lactic acid may occur, directly influencing the pH decrease, and consequently the production of other organic acids (Jackson, 2008). This acidification profile was observed in all acetic fermented assays regardless of the employed production method (Figure 4-runs 12, 13, 14).

During ethanol oxidation, the conversion of ethanol into other volatile organic acids occurs, besides the production of AA (Parrondo et al., 2003). At the end of the production of the acetic fermented product, other short chain fatty acids were analyzed and quantified, such as butyric acid and propionic, being run 14, employing stirred method at $350 \mathrm{rpm}$, the assay with the highest production of those acids: butyric acid $\left(0.1\right.$ to $\left.15 \mathrm{~g} \mathrm{~L}^{-1}\right)$ and propionic $\left(0.9\right.$ to $\left.13 \mathrm{~g} \mathrm{~L}^{-1}\right)$, justifying the considerable ethanol consumption at the end of 28 days. According to Yu et al. (2016), during ethanol oxidation into AA, due to some thermal instability, the production of other organic compounds may occur, such as other acids and ketones, which may be undesirable to the process, because they can alter the AA properties as well as produce esters that can also alter the process.

Regarding Table 4, run 12 (Orleans method) presented the highest acetic fermentation yield conversion in the $21^{\text {st }}$ day, reaching $91.18 \%$ yield, indicating that the process is favorable to valorize ethanol from CWP, also enabling the highest total concentration yield and volumetric productivity of AA in 15 days, $1.10 \%$ and $0.11 \mathrm{~g} \mathrm{~L}^{-1} \mathrm{~h}^{-1}$, respectively.

The alcoholic raw material ethanol from CWP and the Orleans acetic fermented production process were efficient to produce vinegar, meeting the requirements of FAO (2016), which requires a minimum composition of $4 \%$ of AA (40 g L-1) so that the vinegar is adequate to human consumption. Besides, AA may be employed at large scale commercial applications such as in the areas of cosmetic, medicines, beverages, and food preservation, due to its nutritive, antioxidant, and astringent properties, among other applications (Kucerova-Chlupacova et al., 2020; Pal \& Nayak, 2017), being those future applications for the AA obtained from the CWP. 
The assay with the lowest AA production was the one that employed the aerated method with airflow ratio 1:5 vvm, $3.28 \pm 0.14 \mathrm{~g} \mathrm{~L}^{-1}$ in 23 days of production enabling a final ethanol concentration of $11.79 \pm 0.45 \mathrm{~g} \mathrm{~L}^{-1}$ and final $\mathrm{pH}$ of $3.24(28$ days).

The stirred method $(350 \mathrm{rpm})$ produced an intermediate concentration of AA, $19.65 \pm 0.41 \mathrm{~g} \mathrm{~L}^{-1}$, in 16 days of production. The residual ethanol concentration in 28 days of process was $1.34 \pm 0.25 \mathrm{~g} \mathrm{~L}^{-1}$ and $\mathrm{pH}$ of 3.22. Lustrato et al. (2013) obtained, with cheese whey alcoholic fermented product and A. aceti (DSM- G3508 strain), $8.70 \mathrm{~g} \mathrm{~L}^{-1}$ of AA in 11 days of fermentation. The authors used stirred method at $250 \mathrm{rpm}$, airflow ratio $2: 1 \mathrm{vvm}, 32^{\circ} \mathrm{C}$, and initial concentration of ethanol of $11.92 \mathrm{~g} \mathrm{~L}^{-1}$. The value of AA was lower than the one achieved in the present study to the same process time of 12 days $\left(18.25 \pm 0.21 \mathrm{~g} \mathrm{~L}^{-1}\right)$.

The acetic cell biomass production, presented in Figure 4 (runs 12, 13, 14) was 0.45 to $4.20 \mathrm{~g} \mathrm{~L}^{-1}$. From the point when bacterium population is stable and on, there is a decrease in the AA content. According to Mesa, Caro, \& Cantero (1996), as the acidification rate decreases, the acetic bacteria enter the stationary phase followed by the microbial death phase. Besides, due to the acetic bacteria sensitivity regarding the lack of oxygen, stirring instabilities or aeration higher than $30 \mathrm{~s}$ can be enough to modify the bacterium population, modifying the bacteria metabolism, decreasing AA production, or still degrading the AA produced (Muraoka, Watabe, Ogasawara, \& Takahashi, 1983).

\subsection{Total chemical and biochemical oxygen demand removal}

The organic load present in CWP before the fermentations was 668,300 $\mathrm{mg} \mathrm{L}^{-1}$ of COD and 341,000 mg L-1 BOD. After each fermentation stage, for the best production stage, COD and BOD levels were quantified again, after filtrating the fermented to remove the biomass. The values obtained for COD were 515,000 $\mathrm{mg} \mathrm{L}^{-1}$ (alcoholic fermentation) and 220;000 mg L-1 (acetic fermentation), and for BOD, 275,000 $\mathrm{mg} \mathrm{L}^{-1}$ (alcoholic fermentation) and 105,000 $\mathrm{mg} \mathrm{L}^{-1}$ (acetic fermentation) indicating a reduction of $60 \%$ for COD and of $65 \%$ for BOD, evidencing that the nutrients initially presented in the CWP were consumed. Lustrato et al. (2013) using cheese whey and two-step alcoholic fermentations (K. marxianus Y102 strain and acetic by the stirred method and A. aceti DSM-G3508 strain) obtained a COD reduction of only $28.8 \%$ a lower result than our research.

\section{Discussion}

Low initial $\mathrm{pH}$ values were more favorable to ethanol production; low initial values of this variable force the yeast to use more energy to pump $\mathrm{H}^{+}$ions from the cell, instead of using the energy in the biomass formation; consequently, this leads to a higher ethanol yield, because more lactose is used to produce energy instead of biomass formation (Christensen et al., 2011).

The excess of lactose from the CWP was verified to disfavor the ethanol production, causing inhibition according to Figure 3-run 7 to 8. This same behavior was also reported by Andrews (1968) in which the author indicated that there is an inhibition effect by substrate excess in the microorganism growth in batch process.

Marx, Brandling, and Gryp (2012) describe that in a culture medium with high initial substrate concentration (> $200 \mathrm{~g}$ $\mathrm{L}^{-1}$ ) there is a prolongation of the complete utilization of sugar and lower final ethanol concentration, due to the high osmotic pressure in the cellular interior, which causes the cell wall to be damaged and rupture, cell plasmolysis, causing the death of the yeast. Thus, there will be inhibition at high sugar concentrations in ethanol production (Figure 3 - run 7 to 8 ).

Regarding temperature, also negatively significant, Ghanadzadeh \& Ghorbanpour (2012) report that high temperatures cause denaturation of ribosomes, enzymes, and changes in membrane fluidity.

Láinez, Ruiz, Arellano-Plaza, and Martínez-Hernández (2019) explain in their study that differences such as the ones found in the present research regarding ethanol yield (Table 3), may be explained by the fermentation parameters variations, such as initial $\mathrm{pH}$, temperature, agitation, and nutrient supplementation. The process variables (temperature, $\mathrm{pH}$, and substrate 
concentration) also influence the enzyme's action produced by the $K$. marxianus in the hydrolysis of the lactose contained in the CWP (Nelson \& Cox, 2014).

After determining the best ethanol production condition, the acetic fermentation stage was performed, employing the Orleans, aerated, and stirred methods. Using the Orleans method, $42.30 \pm 0.08 \mathrm{~g} \mathrm{~L}^{-1}$ AA was achieved from $47.18 \pm 0.05 \mathrm{~g} \mathrm{~L}^{-1}$ initial ethanol concentration. Aquarone and Zancanaro (1983) claim that an acetic process is industrially viable when it reaches $\cong 76 \%$ of yield. Thus, the acetic fermentation yield was evaluated and the production was considered favorable, since it reached a yield $\left(\mathrm{Y}_{\mathrm{Ac}}\right)$ of $91.18 \%$ in 21 days of fermentation. This value is higher than the obtained by Lustrato et al. (2013), 88.9\%, using ethanol from cheese whey in the production of AA, and Parrondo et al. (2003), 84\% of AA with the bacterium Acetobacter pasteurianus and ethanol from whey. Therefore, aiming at industrial applications, the results of this research show that the developed process can be considered economically viable. Still, we can evidence that this high yield can be due to low evaporation of volatile compounds, which can be attributed to the kind of process chosen, Orleans, which is performed in a static way and also because of the thermal condition $\left(32^{\circ} \mathrm{C}\right)$. Besides those factors, it is valid to highlight that the bacteria from the genus Acetobacter are employed in industrial vinegar production, due to their high capacity in oxidizing ethanol, high resistance at high AA content, and low pH (Nakano et al., 2006).

Among the acetic methods used, the Orleans method was the most efficient in the conversion of ethanol into AA. This method is the oldest technique to produce vinegar, and it is known as slow, superficial, or stationary, and is reported to be the best process to produce fine quality table vinegar or AA. Vinegar produced by this method present better smells due to the formation of esters, besides superior quality, due to the natural maturation of vinegar (Guizani \& Mothershaw, 2006).

The study performed by Toit et al. (2006) showed that the micro-oxygenation of the medium stimulates the acetic bacteria growth. Even so, the aerated method in this study had the lowest AA production $\left(3.28 \pm 0.14 \mathrm{~g} \mathrm{~L}^{-1}\right)$ compared to the other evaluated methods.

Guillamón and Mas (2011) report that the dissolved oxygen concentration has a significant effect on the production rate of AA by acetic bacteria, and that the cells are extremely sensitive to the lack of oxygen, as well as they can be inactivated due to high AA concentrations in the medium. The authors also mention that the oxygen deficiency in the medium causes irreversible damages to the bacterial cells, and that is why this is considered the main cause of hindrance in AA production in vinegar submerged fermentation. Muraoka et al. (1983) also describe that the higher the AA percentage in the medium, the higher will be the cell damage due to lack of oxygen. As the ethanol oxidation into AA occurs, the acetic bacteria require a high rate of oxygen transfer at the air:liquid interface (Krusong, Yaiyen, \& Pornpukdeewatana, 2015). Thus, the oxygen concentration used in this assay, $1: 5 \mathrm{vvm}\left(0.8 \mathrm{~L} \mathrm{~min}^{-1}\right)$, may have been insufficient, disfavoring cell multiplication and resulting in a lower conversion of ethanol into AA. After 10 days of process, the AA production is observed to stop and the process tends to stationary phase, which corroborates to the oxygen deficiency in the medium.

In the stirred process (Figure 4 (b)), there is almost complete exhaustion of ethanol, however, a high AA production was not observed. As already reported, the oxygen concentration available in the medium significantly influences the production rate of AA by acetic bacteria. Tesfaye, Morales, García-Parrilla, \& Troncoso (2002) report that excessive oxygen supply may affect the cell metabolism, increasing the production of volatile compounds, reducing the quality and the yield of the product. Through the behavior obtained in the stirred process, one can say that the oxygen supply provided by the stirring ( $350 \mathrm{rpm}$ ) may have been excessive, disfavoring the high production of AA and favoring the production of other volatile fatty acids.

At ethanol concentrations between 15-10 $\mathrm{g} \mathrm{L}^{-1}$, the cellular growth stops and AA degradation begins, this behavior was observed for the 3 employed methods. Gullo, Verzelloni, and Canonico (2014) report that continuous submerged cultures in which the ethanol content decreases and there is a high AA concentration, the specific growth of acetic bacteria is influenced. 
Besides (Figure 4), after the maximum AA production, it is verified the beginning of the degradation/consumption of it. In cultivations using ethanol to produce AA, the acetic bacteria present three growth phases, in which first they grow completely oxidizing ethanol into AA, and then they stop growing for a period of time, and later, they multiply again using the accumulated AA during the overoxidation phase or acetate peroxidation (Gullo et al., 2014; Mullins \& Kappock, 2013). This expression, acetate peroxidation, is used to designate the phenomena of aerobic acetate anabolism by AA bacteria. This fact is consistent with the observed aspect for the growth curves and production of AA by A. aceti, which is better observed in runs 12 and 13, runs where an intensive consumption of AA with a parallel increase in cell biomass of A. aceti. Thus, to avoid acetate oxidation, the necessity to finish vinegar fermentation is evident, when there is still a non-limiting concentration of ethanol from CWP in the medium. Mullins and Kappock (2013) still explain that this superoxidation interefers in the mechanism responsible for the AA resistance since the AA consumption causes resistance to it.

Regarding the initial organic load reduction in the CWP, the cultivation strategies and the microorganism used in this research are seen to have been able to consume the nutrients from the CWP in the best conditions - alcoholic fermented: K. marxianus CCT 4086, $29^{\circ} \mathrm{C}, \mathrm{pH} 4.5$, and $88 \mathrm{~g} \mathrm{~L}^{-1}$ lactose and acetic fermented: A. aceti CCT 2565, Orleans method, $32^{\circ} \mathrm{C}$, 20 days - enabling significant reductions of both COD as well as BOD, thus demonstrating that the strategy adopted in this research was a viable alternative to be implemented in industries that generate $\mathrm{CPW}$, that aim to convert the CWP through biotechnological processes into new products of high added value.

\section{Conclusion}

In the first fermentation stage (alcoholic), besides the results showing a high conversion of the CWP lactose into ethanol, the K. marxianus CCT 4086 behavior regarding the consumption of the substrate lactose was elucidated, evidencing that the factors temperature, $\mathrm{pH}$, and the CWP lactose concentration itself are significant in ethanol production by this yeast. While in the second fermentation (acetic), the ethanol from CWP could be used in the oxidation to AA by A. aceti CCT 2565 reaching the AA content recommended by FAO, in addition to considerable process efficiency. This shows the potential of the subproduct CWP to generate a product that is compatible with the industrially produced vinegar. Still, the oxygen and ethanol concentrations were verified to be influent factors to produce AA by A. aceti CCT 2565. It was evidenced that at low ethanol concentrations or in the absence of it, the bacterium A. aceti CCT 2565 initiates the overoxidation phase, being necessary to finish the vinegar production process from ethanol from CWP, when there is still a concentration not lower than $15 \mathrm{~g} \mathrm{~L}^{-1}$ of it. Orleans method, despite being considered a slow process, was the one that presented the best conversions of ethanol from CWP into AA, compatible with industrially produced vinegar by other methods. This study elucidated gaps about the behavior of the microorganism and strategies adopted to efficiently use the CWP, and that can aid in the development of future researches, aiming to increase the productivity of AA by faster and commercially applicable methods. It was still possible to identify other potential bioproducts besides ethanol and AA, such as the prebiotic (bacteria) and probiotic microbial biomass (yeast), which can be employed in human or animal feed. Potential organic acids were also identified for distinct applications. There was also a considerable decrease of the organic load of the CWP at the end of the fermentative processes, demonstrating that this sequence makes it an environmentally correct, sustainable, and practicable process, being a rentable and viable alternative to fully value the CWP of the Western Region of Paraná. After concluding this study, it is noted the there is still a need to further the study concerning the production of acetic acid from ethanol from CWP. As suggestions for future stages, there are the evaluation of the influence of the dissolved oxygen in the medium, buffering of the medium $\mathrm{pH}$, conduction of a process through feed batch, that is, perform the addition of ethanol from CWP when it is close to a limiting concentration, among other factors that can be pertinent and directly influence in the maximum conversion of the ethanol from CWP into AA. Posteriorly, it is suggested to test the sequential process in pilot scale, quantify and identify all the potential products formed and evaluate separation and 
purification processes of the formed products. Lastly, if the priority product of interest is the acetic fermented (vinegar), to perform sensorial tests for the consumer acceptance, as well as evaluate legislative requirements for framing the product for commercial purposes.

\section{Acknowledgments}

This study was financed in part by the Coordenação de Aperfeiçoamento de Pessoal de Nível Superior - Brasil (CAPES) - Finance Code 001 as well as the Conselho Nacional de Desenvolvimento Científico e Tecnológico (CNPq) and Fundação Araucária. The authors acknowledge the Sooro Renner Nutrição S.A. for ceding the cheese whey permeate and provide research opportunities.

\section{References}

ABIQ. (2018). Associação Brasileira das Indústrias de Queijo. Queijos no Brasil. https://www.abiq.com.br/queijos_ler.asp?cod igo $=1910 \&$ codigo_categoria $=6 \&$ codigo_subcategoria $=30$

Andrade, R. L. P., \& Martins, J. F. P. I. (2002). Influência da adição da fécula de batata doce (Ipomoea Batatas L.) sobre a viscosidade do permeado de soro de queijo. Ciência e Tecnologia de Alimentos, 22(3), 249-253.

Andrews, J. F. (1968). A mathematical model for the continuous culture of microorganisms utilizing inhibitory substrates. Biotechnology and Bioengineering, 10(6), 707-723. https://doi.org/10.1002/bit.260100602

Aquarone, E., \& Zancanaro, O. J. (1983). Vinagres. In E. Aquarone, A. U. Lima, \& W. Borzani (Eds.), Alimentos e bebidas produzidos por fermentação.

Barros Neto, B., Bruns, R. E., \& Scarminio, I. S. (2010). Como fazer experimentos - Aplicações na ciência e na indústria.

Budak, N. H., Aykin, E., Seydim, A. C., Greene, A. K., \& Guzel-Seydim, Z. B. (2014). Functional Properties of Vinegar. Journal of Food Science, 79(5). https://doi.org/10.1111/1750-3841.12434

Carvalho, F., Prazeres, A. R., \& Rivas, J. (2013). Cheese whey wastewater: Characterization and treatment. Science of the Total Environment, 445-446, 385396. https://doi.org/10.1016/j.scitotenv.2012.12.038

Chen, H., Chen, T., Giudici, P., \& Chen, F. (2016). Vinegar Functions on Health: Constituents, Sources, and Formation Mechanisms. Comprehensive Reviews in Food Science and Food Safety, 15(6), 1124-1138. https://doi.org/10.1111/1541-4337.12228

Cho, Y. J., Kim, D. H., Jeong, D., Seo, K. H., Jeong, H. S., Lee, H. G., \& Kim, H. (2018). Characterization of yeasts isolated from kefir as a probiotic and its synergic interaction with the wine byproduct grape seed flour/extract. LWT- Food Science and Technology, 90, 535-539. https://doi.org/10.1016/j.lwt.2018.01.010

Christensen, A. D., Kádár, Z., Oleskowicz-Popiel, P., \& Thomsen, M. H. (2011). Production of bioethanol from organic whey using Kluyveromyces marxianus. Journal of Industrial Microbiology and Biotechnology, 38(2), 283-289. https://doi.org/10.1007/s10295-010-0771-0

Diniz, R. H. S., Rodrigues, M. Q. R. B., Fietto, L. G., Passos, F. M. L., \& Silveira, W. B. (2013). Biocatalysis and Agricultural Biotechnology Optimizing and validating the production of ethanol from cheese whey permeate by Kluyveromyces marxianus UFV-3. Biocatalysis and Agricultural Biotechnology, 3(2), 1-7. https://doi.org/10.1016/j.bcab.2013.09.002

Diniz, R. H. S., Silveira, W. B., Fietto, L. G., \& Passos, F. M. L. (2012). The high fermentative metabolism of Kluyveromyces marxianus UFV-3 relies on the increased expression of key lactose metabolic enzymes. Antonie van Leeuwenhoek, International Journal of General and Molecular Microbiology, 101(3), 541550. https://doi.org/10.1007/s10482-011-9668-9

Dong, Z. Y., Liu, Y., Xu, M., Zhang, T. H., Ren, H., Liu, W., \& Li, M. Y. (2020). Accelerated aging of grape pomace vinegar by using additives combined with physical methods. Journal of Food Process Engineering, 43(6). https://doi.org/10.1111/jfpe.13398

Fao. (2016). Brazil Dairy, Cheese Production by Year. Retrieved from https://usdabrazil.org.br/wp-content/uploads/2020/06/dairy-and-products-annual-4.pdf

Ferreyra, M., Schvab, M., Davies, C., Gerard, L., \& Hours, R. (2012). Influencia del caudal de aire, temperatura y velocidad de agitación en el proceso discontinuo de acetificación para la obtención de vinagre de naranja (Citrus sinensis var. W. navel). Scientia Agropecuaria, 1, 61-65. Retrieved from http://www.redalyc.org/pdf/3576/357633701008.pdf

Ganju, S., \& Gogate, P. R. (2017). A review on approaches for efficient recovery of whey proteins from dairy industry effluents. Journal of Food Engineering, 215, 84-96. https://doi.org/10.1016/j.jfoodeng.2017.07.021

Garcia, H. A. (2021). 20 anos de Sooro Renner: potencial humano, tecnologia e inovação movem a indústria. Retrieved September 16, 2021, from 20 anos de Sooro Renner: potencial humano, tecnologia e inovação movem a indústria website: https://sooro.com.br/noticias/20-anos-de-sooro-renner-potencial-humanotecnologia-e-inovacao-movem-a-industria/

Ghanadzadeh, H., \& Ghorbanpour, M. (2012). Optimization Of Ethanol Production From Cheese Whey Fermentation In A Batch-Airlift Bioreactor. Journal of Bioengineering \& Biomedical Science, 02(02). https://doi.org/10.4172/2155-9538.1000111 
Gomes, R. J., Borges, M. de F., Rosa, M. de F., Castro-Gómez, R. J. H., \& Spinosa, W. A. (2018). Acetic acid bacteria in the food industry: Systematics, characteristics and applications. Food Technology and Biotechnology, 56(2), 139-151. https://doi.org/10.17113/ftb.56.02.18.5593

Guillamón, J. M., \& Mas, A. (2011). Acetic Acid Bacteria. In R. G. Alfonso V. Carrascosa, Rosario Muñoz (Ed.), Molecular Wine Microbiology (pp. 227-255). https://doi.org/https://doi.org/10.1016/B978-0-12-375021-1.10009-8

Guizani, N., \& Mothershaw, A. (2006). Fermentation: general principles. In T. \& Francis (Ed.), Handbook of Food Science, Technology, and Engineering (pp. 61-68). London.

Gullo, M., Verzelloni, E., \& Canonico, M. (2014). Aerobic submerged fermentation by acetic acid bacteria for vinegar production: Process and biotechnological aspects. Process Biochemistry, 49(10), 1571-1579. https://doi.org/10.1016/j.procbio.2014.07.003

Güneser, O., Karagül-Yüceer, Y., Wilkowska, A., \& Kregiel, D. (2016). Volatile metabolites produced from agro-industrial wastes by Na-alginate entrapped Kluyveromyces marxianus. Industrial Microbiology Volatile, 47(4), 965-972. https://doi.org/10.1016/j.bjm.2016.07.018

Haddish, K. (2015). Production of Single Cell Protein from Fruit of Beles (Opuntia Ficus-Indica L.) Peels Using Saccharomyces cerevisiae. Journal of Microbiology \& Experimentation, 2(7), 212-214. https://doi.org/10.15406/jmen.2015.02.00073

Ho, C. W., Lazim, A. M., Fazry, S., Zaki, U. K. H. H., \& Lim, S. J. (2017). Varieties, production, composition and health benefits of vinegars: A review. In Food Chemistry. https://doi.org/10.1016/j.foodchem.2016.10.128

Illanes, A. (2016). Lactose: Production and Upgrading. In Lactose- Derived Prebiotics (pp. 1-33). Academic Press.

Jackson, R. S. (2008). Fermentation. In Wine science: principles and applications. (pp. 332-417). Academic Press.

Karim, A., Gerliani, N., \& Aïder, M. (2020). Kluyveromyces marxianus: An emerging yeast cell factory for applications in food and biotechnology. International Journal of Food Microbiology, 333, 108818. https://doi.org/10.1016/j.ijfoodmicro.2020.108818

Key, B., Kohl, A.-K., Elflein, J., Puri-Mirza, A., Sapun, P., \& Cherowbrier, J. (2021). Production of cheese in Brazil from 2010 to 2019. Statista Research Department website: https:/www.statista.com/statistics/1004455/brazil-cheese-production-volume/

Khezri S., M.M., S., I., S., M., D., \& P., D. (2016). Whey: characteristics, applications and health aspects. 3rd International Conference on Science and Engineering, 1-9. Retrieved from www.3icesconf.com

Krusong, W., \& Tantratian, S. (2014). Acetification of rice wine by Acetobacter aceti using loofa sponge in a low-cost reciprocating shaker. Journal of Applied Microbiology, 117(5), 1348-1357. https://doi.org/10.1111/jam.12634

Krusong, W., Yaiyen, S., \& Pornpukdeewatana, S. (2015). Impact of high initial concentrations of acetic acid and ethanol on acetification rate in an internal Venturi injector bioreactor. Journal of Applied Microbiology, 118(3), 629-640. https://doi.org/10.1111/jam.12715

Kucerova-Chlupacova, M., Halakova, D., Majekova, M., Treml, J., Stefek, M., \& Soltesova, M. (2020). Chemico-Biological Interactions ( 4-Oxo-2thioxothiazolidin-3-yl ) acetic acids as potent and selective aldose reductase inhibitors. Chemico-Biological Interactions, 332, 109286. https://doi.org/10.1016/j.cbi.2020.109286

Lagrange, V., E Dallas, P. (1997). Inovação de Produto com Concentrados de Proteína de Soro de Leite dos USA. Boletim Da Sociedade Brasileira de Ciência e Tecnologia de Alimentos, 31(1), 17-21.

Láinez, M., Ruiz, H. A., Arellano-Plaza, M., \& Martínez-Hernández, S. (2019). Bioethanol production from enzymatic hydrolysates of Agave salmiana leaves comparing S. cerevisiae and K. marxianus. Renewable Energy, 138, 1127-1133. https://doi.org/10.1016/j.renene.2019.02.058

Lane, M. M., \& Morrissey, J. P. (2010). Kluyveromyces marxianus : A yeast emerging from its sister's shadow. Fungal Biology Reviews, 24(1-2), 17-26. https://doi.org/10.1016/j.fbr.2010.01.001

Lazaro, C. Z., Vich, D. V., Hirasawa, J. S., \& Varesche, M. B. A. (2012). Hydrogen production and consumption of organic acids by a phototrophic microbial consortium. International Journal of Hydrogen Energy, 37(16), 11691-11700. https://doi.org/10.1016/j.ijhydene.2012.05.088

Lustrato, G., Salimei, E., Alfano, G., Belli, C., Fantuz, F., Grazia, L., \& Ranalli, G. (2013). Cheese whey recycling in traditional dairy food chain: effects of vinegar from whey in dairy cow nutrition. Acetic Acid Bacteria, 2(1s), 8. https://doi.org/10.4081/aab.2013.s1.e8

Lynch, K. M., Zannini, E., Wilkinson, S., Daenen, L., \& Arendt, E. K. (2019). Physiology of Acetic Acid Bacteria and Their Role in Vinegar and Fermented Beverages. Comprehensive Reviews in Food Science and Food Safety, 18(3), 587-625. https://doi.org/10.1111/1541-4337.12440

Marx, M., \& Kulozik, U. (2018). Thermal denaturation kinetics of whey proteins in reverse osmosis and nanofiltration sweet whey concentrates. International Dairy Journal, 85, 270-279. https://doi.org/10.1016/j.idairyj.2018.04.009

Marx, S., Brandling, J., \& Gryp, P. Van der. (2012). Ethanol production from tropical sugar beet juice. African Journal of Biotechnology, 11(54), 11709-11720. https://doi.org/10.5897/ajb12.1171

Mesa, M. M., Caro, I., \& Cantero, D. (1996). Viability reduction of Acetobacter aceti due to the absence of oxygen in submerged cultures. Biotechnology Progress, 12(5), 709-712. https://doi.org/10.1021/bp960032j

Mirzaei, M., Mirdamadi, S., Ehsani, M. R., \& Aminlari, M. (2018). Production of antioxidant and ACE-inhibitory peptides from Kluyveromyces marxianus protein hydrolysates: Purification and molecular docking. Journal of Food and Drug Analysis, 26(2), 696-705.

Mullins, E. A., \& Kappock, T. J. (2013). Functional analysis of the acetic acid resistance (aar) gene cluster in Acetobacter aceti strain 1023. Acetic Acid Bacteria, 


\section{2(1s), 3. https://doi.org/10.4081/aab.2013.s1.e3}

Muraoka, H., Watabe, Y., Ogasawara, N., \& Takahashi, H. (1983). Trigger of Damage by Oxygen Deficiency to the Acid Production System during Submerged Acetic Fermentation with Acetobacter aceti : Journal of Fermentation Technology, 61(1), 89-93.

Murari, C. S., Machado, W. R. C., Schuina, G. L., \& Bianchi, V. L. Del. (2019). Optimization of bioethanol production from cheese whey using Kluyveromyces marxianus URM 7404. Biocatalysis and Agricultural Biotechnology, 20(April), 101182. https://doi.org/10.1016/j.bcab.2019.101182

Murari, C. S., Silva, D. C. M. N. da, Schuina, G. L., Mosinhahti, E. F., \& Bianchi, V. L. del. (2018). Bioethanol Production from Dairy Industrial Coproducts Bioethanol Production from Dairy Industrial Coproducts. BioEnergy Research, 12, 112-122. https://doi.org/10.1007/s12155-018-9949-5

Nagodawithana, T. W., \& Steinkraus, K. H. (1976). Influence of the Rate of Ethanol Production and Accumulation on the Viability of Saccharomyces cerevisiae in " Rapid Fermentation ". Appied and Environmental Microbiology, 31(2), 158-162.

Nakano, S., \& Fukaya, M. (2008). Analysis of proteins responsive to acetic acid in Acetobacter: Molecular mechanisms conferring acetic acid resistance in acetic acid bacteria. International Journal of Food Microbiology, 125(1), 54-59. https://doi.org/10.1016/j.ijfoodmicro.2007.05.015

Nakano, S., Fukaya, M., \& Horinouchi, S. (2006). Putative ABC transporter responsible for acetic acid resistance in Acetobacter aceti. Applied and Environmental Microbiology, 72(1), 497-505. https://doi.org/10.1128/AEM.72.1.497-505.2006

Nelson, D. L., \& Cox, M. M. (2014). Princípios de bioquímica de Lehninger.

Padilla, B., Frau, F., Ruiz-matute, A. I., Montilla, A., Belloch, C., Manzanares, P., \& Corzo, N. (2015). Production of lactulose oligosaccharides by isomerisation of transgalactosylated cheese whey permeate obtained by $\beta$-galactosidases from dairy Kluyveromyces. Journal of Dairy Research, 356-364. https://doi.org/10.1017/S0022029915000217

Pal, P., \& Nayak, J. (2017). Acetic Acid Production and Purification: Critical Review Towards Process Intensification. Separation and Purification Reviews, 46(1), 44-61. https://doi.org/10.1080/15422119.2016.1185017

Parrondo, J., Herrero, M., García, L. A., Díaz, M., \& Brew, J. I. (2003). A Note - Production of Vinegar from Whey. Journal of the Institute of Brewing, 109(4), 356-358. https://doi.org/DOI: 10.1002/j.2050-0416.2003.tb00610.x

Passos, F. R. dos, Maestre, K. L., Silva, B. F. da, Rodrigues, A. C., Triques, C. C., Garcia, H. A., Fiorese, M. L. (2021). Production of a synbiotic composed of galacto-oligosaccharides and Saccharomyces boulardii using enzymatic-fermentative method. Food Chemistry, 353. https://doi.org/10.1016/j.foodchem.2021.129486

Pazuch, C. M., Kalschne, D. L., Siepmann, F. B., Marx, I. M. G., de Oliveira, T. C. G., Spinosa, W. A., Colla, E. (2020). Optimization and characterization of vinegar produced from rice bran. Food Science and Technology, 40(3), 608-613. https://doi.org/10.1590/fst.13919

Raspor, P., \& Goranovič, D. (2008). Biotechnological applications of acetic acid bacteria. Critical Reviews in Biotechnology, 28(2), 101-124. https://doi.org/10.1080/07388550802046749

Samuel, O., Lina, J., \& Ifeanyi, O. (2016). Production of Vinegar from Oil-palm Wine Using Acetobacter aceti Isolated from Rotten Banana Fruits. Universal Journal of Biomedical Engineering, 4(1), 1-5. https://doi.org/10.13189/ujbe.2016.040101

Sievers, M., \& Swings, J. (2015). Acetobacter . Bergey's Manual of Systematics of Archaea and Bacteria, 1-7. https://doi.org/10.1002/9781118960608.gbm00876

Spinosa, W. A., Júnior, S., Galvan, D., Fiorio, J. L., Jorge, R., \& Castro, H. (2015). Vinegar rice (Oryza sativa L.) produced by a submerged fermentation process from alcoholic fermented rice. Food Science and Technology, 35(1), 196-201.

Talabardon, M., Schwitzguébel, J. P., \& Péringer, P. (2000). Anaerobic thermophilic fermentation for acetic acid production from milk permeate. Journal of Biotechnology, 76(1), 83-92. https://doi.org/10.1016/S0168-1656(99)00180-7

Tesfaye, W., Morales, M. L., García-Parrilla, M. C., \& Troncoso, A. M. (2002). Wine vinegar: Technology, authenticity and quality evaluation. Trends in Food Science and Technology, 13(1), 12-21. https://doi.org/10.1016/S0924-2244(02)00023-7

Toit, W. Du, Lisjak, K., Marais, J., \& Du Toit, M. (2006). The Effect of Micro-oxygenation on the Phenolic Composition, Quality and Aerobic Wine-Spoilage Microorganisms of Different SouthAfrican Red Wines. South African Journal of Enology and Viticulture, 27(1), 57-67.

Trigueros, D. E. G., Fiorese, M. L., Kroumov, A. D., Hinterholz, C. L., Nadai, B. L., \& Assunc, G. M. (2016). Medium optimization and kinetics modeling for the fermentation of hydrolyzed cheese whey permeate as a substrate for Saccharomyces cerevisiae var. boulardii. Biochemical Engineering Journal, 110, 7183. https://doi.org/10.1016/j.bej.2016.02.014

Wehr, H. M., \& Frank, J. F. (2004). American Public Health Association.

Xie, Y., Zhang, H., Liu, H., Xiong, L., Gao, X., Jia, H., ... Han, T. (2015). Hypocholesterolemic effects of Kluyveromyces marxianus M3 isolated from Tibetan mushrooms on diet-induced hypercholesterolemia in rat. Brazilian Journal of Microbiology, 46(2), 389-395. https://doi.org/10.1590/S1517-838246220131278

Yadav, J. S. S., Yan, S., Pilli, S., Kumar, L., Tyagi, R. D., \& Surampalli, R. Y. (2015). Cheese whey: A potential resource to transform into bioprotein, functional/nutritional proteins and bioactive peptides. Biotechnology Advances, 33(6), 756-774. https://doi.org/10.1016/j.biotechadv.2015.07.002

Yu, L., Zhuang, X., Bai, L., Li, F., He, W., Li, G., \& Huang, J. (2016). Acetic acid production from the hydrothermal transformation of organics in waste liquid crystal display panels. Journal of Cleaner Production, 113, 925-930. https://doi.org/10.1016/j.jclepro.2015.11.056

Zacarchenco, P. B., Dender, A. G. F., Spadoti, L. M., Galfina, D. A., Trento, F. K. H. s., \& Silva, A. T. P. (2012). Permeado de soro de leite desproteinizado. 
Research, Society and Development, v. 10, n. 13, e212101321082, 2021

(CC BY 4.0) | ISSN 2525-3409 | DOI: http://dx.doi.org/10.33448/rsd-v10i13.21082

Guia de Referência Do Setor Lácteo. Anuário Leite e Derivados.

Zoppellari, F., \& Bardi, L. (2013). Production of bioethanol from effluents of the dairy industry by Kluyveromyces marxianus. New Biotechnology, 30(6), 607613. https://doi.org/10.1016/j.nbt.2012.11.017 